\title{
Physics competition to inspire learning and improve soft skills: a case of the Chain Experiment
}

\author{
Daniel Dziob ${ }^{1,2}$ D $\cdot$ Urszula Górska ${ }^{1,3,4} \cdot$ Tomasz Kołodziej $^{1} \cdot$ Mojca Čepič ${ }^{5}$
}

Accepted: 19 August 2020 / Published online: 3 September 2020

(c) The Author(s) 2020

\begin{abstract}
The Chain Experiment competition has been held successfully for 6 years in Poland and is attracting growing interest. The competition provides participants with a task that involves designing and constructing a contraption that is an element in a chain of events that are based on various physical phenomena. The contraptions are then linked together in a chain and made to run consecutively. The operation of a contraption starts when it receives a ball from the preceding contraption and ends when it releases another ball to the next contraption. The process of constructing the contraptions includes elements of design education. This paper examines whether participating in the competition has a positive impact on the soft skills, social abilities and motivation of the participants, as well as their learning performance, mainly in physics. Questionnaires completed after the fifth running of the competition suggest that active participation in the Chain Experiment could have a positive impact on participants' soft skills and their abilities to solve problems, and it might also increase scientific knowledge, general interest in physics and science and motivation to be involved in similar challenges. The claim is that the format of the competition can stimulate versatile development of the participants and is a good way to arouse students' interests in physics and engineering, even in the very early stages of their education.
\end{abstract}

Keywords Physics competition · Informal learning · Soft skills · Scientific practice · Physics education

Daniel Dziob

daniel.dziob@uj.edu.pl

1 Smoluchowski Institute of Physics, Jagiellonian University, Kraków, Poland

2 Department of Biophysics, Jagiellonian University Medical College, Kraków, Poland

3 Psychophysiology Laboratory, Institute of Psychology, Jagiellonian University, Kraków, Poland

4 Department of Neurophysiology, Donders Institute, Radboud University, Nijmegen, The Netherlands

5 Faculty of Education, University of Ljubljana, Ljubljana, Slovenia 


\section{Introduction}

Technological developments mean that many educators and governments are now focused on education in science, technology, engineering and mathematics (STEM). Current reports suggest that learning STEM subjects well creates opportunities for better-paid jobs and decreases the risk of future unemployment (Langdon et al. 2011). However, besides scientific and/or technological knowledge, employers nowadays also expect 'soft skills' (Symonds et al. 2011; Blom and Saeki 2011), which are easier to describe than to define. The literature refers to soft skills as "personality traits, goals, motivations, and preferences that are valued in the labor market, in school, and in many other domains" (Heckman and Kautz 2012) or "social toolkits for success in everyday life in different contexts" (Clara et al. 2018). Among the other skills, communication and discussion abilities, presenting a personal point of view and working in a group are considered as useful soft skills. Many authors point out that besides 'hard' knowledge, soft skills are important for future successful careers (Robles 2012; Heckman and Kautz 2012; Schulz 2008) and thus should be developed from an early educational stage (Santos et al. 2017). The above shows that students in the twenty-first century must acquire a breadth of knowledge about various subjects and soft skills, with the two progressing simultaneously to provide holistic development (Symonds et al. 2011).

Meanwhile, science education in schools involves separating science into more-specific subjects, one being physics. Often, science teachers are tightly bound by curricula formed in a traditional, content-focused way (Aikenhead 2006), which is why many students describe their experience of school science as repeating a list of inconsequential facts or conclusions without reasoning (Mallya et al. 2012). Therefore, the considerable decline in student involvement in science might be a consequence of students' 'disenchantment' with science (Aikenhead 2006; Fensham 2004) and/or the separation between school science and outside-school experiences (Brickhouse and Potter 2001; Aikenhead 2006; Calabrese Barton 1998, 2003). However, even if students' attitudes towards science as a school subject are not positive, they often recognize the profession of scientist as important (Collins et al. 1989; Jenkins and Nelson 2005; Osborne and Collins 2001; Osborne and Dillon 2008; Sjøberg and Schreiner 2005).

Generally, students spend more time out of school than in school (Bell et al. 2009; Falk and Dierking 2010; Rennie 2007). Moreover, studies suggest that involvement in non-school science-related events could strengthen science learning substantially (Calabrese Barton 1998; Fusco and Calabrese Barton 2001; Rahm 2002). Science learning that occurs outside the traditional, formal school realm is called informal learning (Dierking et al. 2003), which has become an important research focus over the past decade, not only in science education (Dierking et al. 2003; Enos et al. 2003; Fallik et al. 2013; Hamilton 2008; Paradise and Rogoff 2009). For clarity, herein we define informal learning as learning activity that takes place outside school and without an externally imposed curriculum.

One form of informal learning is participation in competitions (Verma et al. 2015), i.e. contests among students or groups of students who want to achieve a specific goal or, very often, win an award. Competition usually has a motivational role and increases educational interest in students participating in a particular subject (Ozturk and Debelak 2008; Thrasher 2008; Wankat 2005), especially in science. The most respected competitions in physics are the International Physics Olympiad, the International Young Physicists' Tournament and national Olympiads. These competitions demand very good theoretical knowledge, proficiency in mathematics and advanced experimental skills 
(Campbell and Walberg 2010); therefore, only the most talented students participate to these competitions. Nevertheless, regular school achievements in physics are usually correlated with mathematical abilities. It is not rare that students with good conceptual knowledge of physics obtain bad results in tests if they have low mathematical skills (Meltzer 2002). To encourage such students, interesting options are engineering competitions, such as the Formula SAE race and Chain Experiment competitions, which emphasize engineering experience related to designing, constructing and testing real hardware or contraptions (Dziob et al. 2017; Schuster et al. 2006). Both competitions naturally incorporate design education, with students working towards a unique solution to a pre-defined problem (Haupt 2017) and creating a technological result. In this process, students develop a plan and then implement it through making (Mitcham 2001).

In the Chain Experiment competition, participants cooperate to build a contraption of their own design that is based on several interesting physical phenomena. The term "contraption" is used for the set of mechanisms constructed by each team, which is then connected to other contraptions during the Grand Finale, as described originally in the Slovenian version of the competition (Susman et al. 2017). The process of building a contraption takes several months, usually outside of school, meaning outside of classes and/or outside the building. Successful construction of a contraption, in order to win a competition, usually pushes students to acquire new knowledge and develop technological literacy. During the Grand Finale, when all contraptions are presented, teams join and compete with one another. Participation in the competition is voluntary, and participants can determine the complexity of their construction and may transfer their science experience into designing and creating a contraption in an alternative sphere of their own choice, which has been stressed as an important factor in the relevancy of informal learning (Tal and Dierking 2014). In this process, they implement science phenomena in an actual working machine and search for practical technological solutions, which naturally develops their engineering skills and is an important aspect of technology education (Brown and Brown 2010; Dugger and Naik 2001). Besides acquiring knowledge, a natural consequence of cooperating during the competition (e.g. discussions among participants, making compromises) is the development of soft skills, which is considered one of the many benefits of cooperative learning (Lejk and Wyvill 2001).

However, although Chain Experiment competitions have been described previously (Dziob et al. 2017; Susman et al. 2017), research is yet to be presented concerning how these competitions influence participants' achievements or soft-skills development. At the same time, some aspects (including knowledge and soft skills, considered herein) have been described in the context of activities that are to some extent similar to the Chain Experiment competition (e.g. Klein et al. 2015; McNamara et al. 1999). However, most of those studies were not interested in investigating soft skills and knowledge improvement simultaneously. The present aim is to bridge that gap, to which end we sought to establish how students and teachers perceive the Chain Experiment competition and participation in it and whether a competition can influence participants' skills, attitudes and knowledge. The present research questions (RQs) are as follows.

1. How do participants perceive the form of the Chain Experiment competition?

2. How does the Chain Experiment competition influence participants' soft skills?

3. How does the Chain Experiment competition influence participants' interest in physics and science? 
4. How does the Chain Experiment competition influence participants' scientific knowledge?

5. How does the Chain Experiment competition influence participants' motivation for further learning?

\section{Background of the study}

\section{General description of Chain Experiment competition}

The Chain Experiment competition was introduced in Slovenia in 2005 in cooperation between the University of Ljubljana and the Technical Museum of Slovenia. It started from a promotional demonstration chain experiment that had a motivational and explanatory role for participants and aimed to bring physics closer to everyday life (Susman et al. 2017). In 2013, the Chain Experiment was introduced as a nationwide annual competition in Poland. It has a 1-year development cycle, from demonstrations in schools, through the process of team work focused on designing, testing, preparing documentation, to the final contraption (Dziob et al. 2017).

In the Chain Experiment competition, the main task given to teams of between two and five members is to design and construct a contraption in which a series of events is triggered by a prescribed linking event. The entire design process is regulated by the rules of the Chain Experiment competition (Jagiellonian University, Institute of Physics, 2018) as summarized in Table 1.

During the Grand Finale, all contraptions are linked in one or more chains, each containing a number of different contraptions (see Fig. 1). The first contraption in each chain is triggered by an event equivalent to the linking one, namely by releasing the ball manually into the first contraption. The physics and science phenomena to be used are not prescribed, and participants are given artistic license. For more information and examples of participants' contraptions, see Dziob et al. (2017). Legal issues concerning underage participants mean that each team must have a formal mentor. However, there are no requirements for the mentor except to be of legal age, and also one mentor can supervise more than one team.

One month before the Grand Finale, participants report their progress in a submitted form to ensure participation and timely finalization of the contraption. Participants select the form in which this is done, including sketches and schemes, photographs of the

Table 1 Some rules of the Chain Experiment

\begin{tabular}{ll}
\hline Maximum size (width $\times$ depth $\times$ height) & $120 \mathrm{~cm} \times 70 \mathrm{~cm} \times 150 \mathrm{~cm}$ \\
Operating direction & From right to left \\
Starting point & Shortest dimension, right side at 45-cm height \\
Ending point & Shortest dimension, left side at 45-cm height \\
Maximum operating time & $120 \mathrm{~s}$ \\
Limitations & All scientific laws and phenomena are allowed, the \\
& only restriction being that their use should be safe. \\
& $\begin{array}{l}\text { Electricity can be used only up to } 24 \text { V. External } \\
\text { power sources, dangerous chemicals and the use of } \\
\text { animals are strictly forbidden }\end{array}$ \\
\hline
\end{tabular}



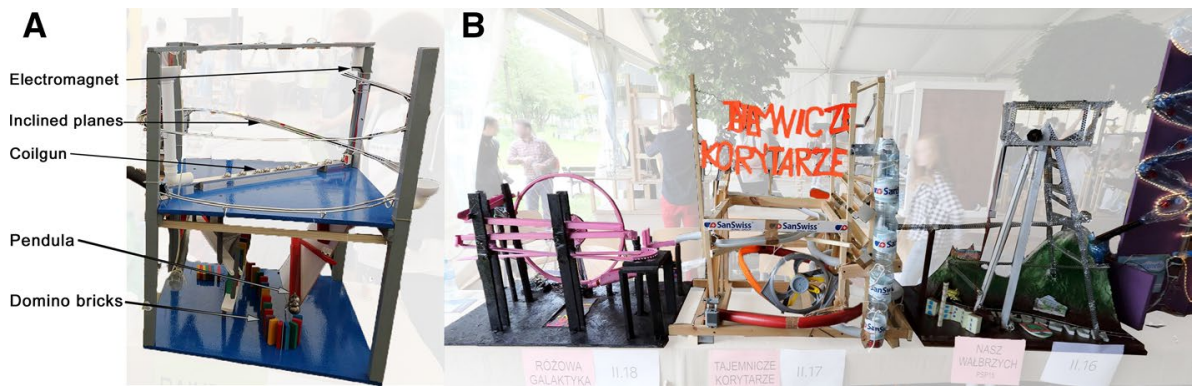

Fig. 1 a An example of an isolated contraption. b Three contraptions linked together by a triggering event marked by a circle. Both photographs were taken during the Grand Finale in 2017

construction of the contraption, video clips or a presentation. This part of the competition was introduced mainly to monitor participants' progress and motivate them to work. The final form of each contraption is assessed at the Grand Finale by an expert jury. Three main criteria are considered, related adequately to aspects of science, technology and design: (a) the originality of the physics laws and phenomena used in the implementation and the participants' ability to explain them, according to age category; (b) the reliability of the contraption (i.e. whether it can operate without external help) versus its complexity; (c) the quality, ingenuity and aesthetics of the contraption, including its unique name and appearance (Dziob et al. 2017). At the end, the best contraptions are awarded prizes in different categories, i.e. kindergarten, primary school (PS), lower-secondary school (L-SS), high school (HS), university and family.

In many aspects, the Chain Experiment competition is similar to various European physics competitions (Jordens and Mathelitsch 2009; Haskell et al. 2000), but it is unique as an exhibition and physics show. Being part of a team that constructs a spectacular contraption, something that the audience appreciates highly, seems more valuable than awards and the competitive character of the competition (Susman et al. 2017). Additionally, in contrast to other competitions that have a relatively rigid and predefined syllabus, the Chain Experiment is open to various aspects of physics.

Further unique aspects of the Chain Experiment are the freedom left for students and the engagement of mentors, which can be observed in the various approaches that students take in accomplishing the task. Also, observations over several years suggest that mentors play different roles in different teams: some teams are more self-reliant and can solve problems and learn new knowledge by themselves, whereas other teams require more guidance. Thus the role of a particular mentor in the work of a particular team is unknown because some teams are more self-reliant than others. The main factor that motivates students to work on the design of their contraption and learn the explanations of the mechanisms used is the competition task itself (Susman et al. 2017).

\section{Chain Experiment as design education}

The process of creating the contraption can be viewed as a realization of design education, which is learning how to apply practical methods, prior knowledge and natural talent to solve problems (Casakin and Goldschmidt 1999). The field of design is expanding rapidly nowadays, such as in fashion, architecture and information technology (IT) (Berk 
2016; Lawson 2006), but at the same time design education remains underrepresented as a school discipline. As a core competency, design comprises communication, collaboration, problem solving, critical thinking and creativity (Berk 2016), which are vital skills in the process of building a contraption. Participants in the Chain Experiment must propose their own solution to the problem defined by the competition rules. However, note that the Chain Experiment competition focuses on not only the design process but also evaluating the final creation and how participants explain it using their knowledge (acquired both prior to and during the design process).

Note, that Chain Experiment task is strongly connected with physics, which formulate a framework for the process of design. It is crucial to understand physics to design the contraption, as well as design is important to realize practically the physics concepts in real, working mechanisms (Zadeh and Satir 2015). Chain Experiment creates space for both, giving the chance for improvement of knowledge learned by repeating error and trial process as well as strengthening abilities of attractive design. The current literature mainly focuses on both design and technology, however introducing them in science courses was also already proposed (Gilbert et al. 2000). Since this important combination is present in Chain Experiment, both physics and design education may profit from each other at every educational stage.

In realizing the entire Chain Experiment as design education, we distinguish three main components that we find to be most important here, namely collaborative learning (Pawson 2016), problem-based learning (Ovesen 2015) and gamification. The third of these is not traditionally mentioned in this framework, but an important aspect in the Chain Experiment is the rivalry between participating teams, which stimulates them to invent a unique contraption that beats the other solutions (Dziob et al. 2017). In the following paragraphs, we discuss all three components together with their manifestation in the Chain Experiment.

\section{Chain Experiment as collaborative learning}

The increased technical development and the need for specialization in recent years have brought important challenges, in which cooperation and efficient teamwork play a key role (Johnson and Johnson 2014). Accordingly, an important part of education is now collaborative learning, in which students form small groups and share responsibilities to achieve a common goal (Johnson et al. 2013). They work together to maximize the benefit to each group member. In such circumstances, students learn not only to respect one another and communicate effectively but also to practice their personal learning abilities, specifically knowledge development, thinking skills, social skills and overall satisfaction (Barkley et al. 2014; Kuo et al. 2012; Schellens and Valcke 2005). Moreover, learning from collaboration encourages critical and creative thinking, develops self-confidence (Springer et al. 1999) and has a positive impact on social acceptance and considering the perspectives of others (Davidson and Major 2014). Above all, collaborative learning naturally creates environment for developing soft skills (Lejk and Wyvill 2001). To cooperate successfully, students must discuss with each other, achieve compromises and work together for a common goal. Many researchers have shown that collaborative learning works well for developing soft skills in different branches, such as economical, technical, IT and vocational courses (Azmir et al. 2011; Cheong 2010; Khalid and Metersad 2016; Zhang 2012).

In particular, the process of constructing a contraption for the Chain Experiment competition may encourage the development of all these skills. Designing and constructing a contraption in which several interesting and not commonly met physics phenomena are applied 
requires participants to collaborate closely. Moreover, the multi-step nature of the construction and the fact that it can be divided into smaller diverse tasks mean that the success of the final contraption depends on group members having complementary skills. The group as a whole starts by designing the contraption (planning, drawing, measuring), after which additional study is often required to extend knowledge of the chosen phenomena so that the latter can be applied effectively, a reliable contraption can be constructed, and the questions of the jury during the competition can be answered. While creating the contraption, participants share knowledge and use it as a product of joint development (Hakkarainen 2009). Knowledge is dealt through the design process, where the most important aspects are its adequacy, usefulness and developmental potential (Bereiter and Scardamalia 2003). A common goal provides an environment in which group members with different knowledge, ideas and experience discuss the task demands freely from various perspectives. During the preparation period, participants work collaboratively and are forced to compromise to achieve the effectiveness and reliability of the various devices combined in the contraption. Feedback during the discussion stimulates participants to revise their ideas and thus make progress. The opinions of participants and mentors as articulated during previous editions of the competition (Dziob et al. 2016) show brainstorming and discussion to be the most frequent ways of making compromises during construction. In this way, the Chain Experiment competition promotes self-esteem, develops individual competences and favours interest in physics.

\section{Chain Experiment as PBL}

Although traditional teaching remains the predominant way of transferring knowledge in science, many teachers endeavour to implement more-active learning approaches (Roehl et al. 2013; English and Kitsantas 2013; Freeman et al. 2014) that are usually implemented in similar ways, namely project-based learning and problem-based learning. Both have the same educational focus and differ only in details (Savery 2006), so even though the Chain Experiment is closer to project-based learning, herein we simply use the acronym PBL when considering the aspects of both project- and problem-based learning. The key aspect of PBL methodology is its focus on an open-ended question or task that has no single correct solution (Barron et al. 1998). Students gain new knowledge by solving the problems that arise while searching for a solution in collaborative groups. In general, students must identify a problem first, learn new concepts and skills, apply the acquired knowledge to the problem solution and finally reflect on their effectiveness (Hmelo-Silver 2004). The net results can be tangible, such as a product, a performance or simply a proposed solution. The best PBL problems are authentic, adjusted to the prior knowledge of participants and geared towards enhancing discussions. They should also stimulate self-directed learning and lead to identifying appropriate learning issues (Des Marchais 1999; Schmidt et al. 2011). Many researchers have found PBL to be a very valuable approach that promotes students' motivation and responsibility for learning by integrating knowledge with practice (Albanese and Mitchell 1993; Blumenfeld et al. 1991; Evensen 2000; Gallagher 1997; Hmelo-Silver 2004; Vernon and Blake 1993), increasing interaction between students and improving social awareness, skills and critical thinking (Gunawardena et al. 1997; Lee and Lim 2012; Newman et al. 1995; Pena-Perez 2000; Stahl 2000). It was also shown that PBL promotes conceptual change (Loyens et al. 2015), which seems to be important due to scientific-oriented task given for participants in the Chain Experiment. 
The Chain Experiment competition provides participants with a well-defined openended practical problem, namely how to connect a series of events in the contraption using physics phenomena. Although the focus is physics, the problem is open and the goal can be achieved with various approaches (including interdisciplinary ones). Participants start by identifying a problem and then discuss various ways of solving it. Designing and constructing the contraption involves two main activities: focusing on devices that together form a contraption, thereby engaging manual and technical skills and considering the underlying physics and science concepts behind the contraption that will be presented and assessed at the Grand Finale. The process of designing and constructing the contraption involves several stages over a few months, during which participants acquire and implement new and restructure already gained (theoretical and procedural) knowledge, verify ideas in practice, reflect on their effectiveness and proceed to the next step, focusing on a different part of the contraption. When undertaking a competition task in groups, they must discuss and present their opinions with adequate scientific reasoning. The discussion while designing and constructing the contraption provided participants with the opportunity to thoughtfully and critically weight their scientific viewpoints and contrast them with outcomes of their investigations (Broughton et al. 2013). This practical verification leads to conceptual change (Cobern 1996). The complexity of the task itself means that participants must work collaboratively and make compromises at the functional level of the contraption and at the social level of the group. Because participants compete in different age categories, the task assessment is also adjusted to the actual educational level of the participants.

\section{Chain Experiment as gamification}

Gamification can be defined as the application of game-based elements (e.g. game mechanics, aesthetics, principles and game thinking) in non-game contexts (Huotari and Hamari 2012; Robson et al. 2015). The main ideas behind this approach are to engage people, enhance learning by motivating and stimulate finding solutions to problems (Apostol et al. 2013; Deterding et al. 2011). The idea of introducing games to teaching is not new, given that digital games have been used for learning in formal environments since the 1960s (Ifenthaler et al. 2012 and references therein; Moncada and Moncada 2014). However, the term "gamification" was introduced a few years ago and is gaining in popularity (Dicheva et al. 2015; Sung and Hwang 2013). The benefits of gamification (or more broadly, gamebased learning; e.g. Ifenthaler et al. 2012) in the educational context are described well in the literature. Among other values, one could emphasize the increase in students' intrinsic motivation and self-efficacy (Banfield and Wilkerson 2014; Seaborn and Fels 2015), the possible motivational effect together with enhanced learning skills (Dicheva et al. 2015; Sadler et al. 2013) and the positive aspect of competition itself (Conklin 2006; Burguillo 2010).

The specific approach of the Chain Experiment competition could also be described in terms of gamification. It is a type of open construction game (like Build a Bridge, SimCity, LEGO Mindstorms and Incredible Machines) that has been brought into the real world, namely to build a full-size working mechanism. Classical construction games and the Chain Experiment competition have a number of similarities. In both, the objectives and rules are clearly defined, and actions are restricted adequately by the game engine and algorithms or physics laws. In a classical construction game, the player chooses a particular level and then moves to the next one upon completion. Correspondingly, when constructing 
the contraption, participants choose the physical phenomena, starting from a simple mechanism and progressing to more-complicated ones.

As a large-scale construction game, the Chain Experiment competition consists of several stages that are essential to accomplishing the task, namely (a) designing the contraption, (b) building and documenting it, and finally (c) presenting the functional contraption with a detailed description at the Grand Finale. Teams compete in various categories to achieve high scores and prizes, which are awarded by the jury in the Grand Finale. However, a very important goal besides the awards is constructing a contraption that functions successfully in a chain in the Grand Finale. The competition maximizes the area of creativity, which is another reason why it is more challenging than many other physics competitions.

\section{Methodology}

The main goal of our study is to find how (if and to what extent) the competition itself motivates the learning of physics or science in general, guides the development of participants' soft skills and encourages them to acquire new knowledge. In particular, we investigate the influence of the Chain Experiment's form, which combines elements of design education manifested in collaborative learning, PBL and gamification. The entire competition process gives participants a chance to go step by step from preparation to the Grand Finale and to observe their development and evaluate themselves in the several months of this process.

\section{Context of study}

The study sample consists of participants from a wide range of educational levels (from PS to HS) who participated in the fifth running of Chain Experiment competition in Krakow, Poland. Table 2 shows the age distribution of participants, who came to the competition from across the whole country. Most participants (i.e. 49\%) live in larger towns of up to 100,000 inhabitants, $18 \%$ come from small cities with 20,000-100,000 inhabitants, $10 \%$ live in small towns up to 20,000 inhabitants and $23 \%$ of participants come from villages. The participants form a cross section through various social strata, and we consider it unlikely that the present results are biased strongly by, for example, the type of town.

Participation in the Chain Experiment competition requires 1-6 months of preparation and involves three main stages. In the first stage, small groups of between two and five participants register with their mentors (teacher or parent) on the competition's website and receive a starter pack containing two metal balls. Over the next few weeks, participants

Table 2 Numbers of participants and corresponding teams in age categories

\begin{tabular}{lllc}
\hline Category & Age span & $\begin{array}{l}\text { Number of } \\
\text { participants }\end{array}$ & $\begin{array}{l}\text { Number } \\
\text { of teams }\end{array}$ \\
\hline Primary school & $6-13$ & 122 & 33 \\
Lower-secondary school & $14-16$ & 236 & 61 \\
High school & $17-19$ & 95 & 24 \\
Family & - & 31 & 8 \\
Total & - & 484 & 126 \\
\hline
\end{tabular}


meet and discuss designs, ideas and schemes of parts of the contraption and realize them. The formal side of meetings is not regulated by the competition rules. Teams could meet and work on the task during lessons, but participant feedback reveals that they meet mostly after regular classes in their free time. The preparation part is the longest stage of the competition, during which educational approaches such as problem-based learning and collaborative learning are necessary to accomplish the task successfully. During this period, participants learn physics on their own when the need arises, share ideas and become used to collaborating effectively in a team.

To stimulate participants to manage their time effectively, the competition rules require documentation of the progress of the contraption's construction 1 month before the Grand Finale. The Grand Finale is the final part of the competition. On that day, all teams arrive at the campus of Jagiellonian University and join their contraptions to create a "chain" of contraptions in which the metal balls pass from one contraption to trigger the next. During the final event, the jury-established from physics faculty staff, doctoral candidates, students and in-service teachers-evaluates the participants' contraptions. Every team is assessed according to three criteria, which are evaluated with regard to the educational level of the participants. In the first criterion, jury members ask about the physical phenomena used in the contraption and verify that the participants can explain them correctly. The participants can discuss the answers as a group, which decreases stress and helps them to recall their knowledge. The second criterion is the complexity and infallibility of the contraption. To assess this, the participants start the contraption and jury members observe its functioning. In the last criterion, the jury assesses the structure of the contraption from an artistic perspective and the relevance of its name. These three criteria are used to evaluate all the contraptions, and the best (around 15\% in each category) receive an award.

\section{Data collection}

To determine whether participating in the Chain Experiment competition has a positive impact on participants' development, we prepared separate questionnaires for participants and mentors and conducted semi-structured interviews with jury members. Both questionnaires covered similar issues and were constructed to address the five main assumptions listed in Table 3. These assumptions relate to participants' development, including soft skills, acquisition of new knowledge, and increased interest and motivation to learn physics or science. Moreover, the participants rated the form of the preparation (working in groups). The questionnaires were prepared in the adopted form of item parcelling, so we asked about the same things (concerning each assumption) multiple times in different ways, using various types of questions that are correlated with one another. Both questionnaires

Table 3 The five assumptions analysed by the participant questionnaire

\begin{tabular}{ll}
\hline No. & Assumption \\
\hline A1 & Working in groups could increase participants' motivation and help them to solve problems \\
A2 & Participating in the competition could have a positive impact on participants' soft skills \\
A3 & Participating in the competition could increase participants' interest in physics and science \\
A4 & Participating in the competition could increase participants' scientific knowledge \\
A5 & $\begin{array}{c}\text { Participating in the competition could motivate participants to further work and undertake } \\
\text { new scientific challenges }\end{array}$ \\
\hline
\end{tabular}


are described and validated in detail below. Because the definition of soft skills can vary among fields (Schulz 2008), similarly to other authors (Schulz 2008; Heckman and Kautz 2012), we focused on some of them, such as communication skills, searching for information, ability to discuss, presenting own opinions and working in a group.

The participant questionnaire comprised 23 questions and is presented in "Appendix 1". Firstly, the participants were asked to mark their age category. In part 1, eight questions asked the participants to self-assess, on a Likert-like scale, various effects of participating in the Chain Experiment competition on their personal soft skills and knowledge. The scale spans from -5 , signifying a high negative impact on the examined factor, to 5, signifying a high positive impact, with response 0 meaning no influence. Answers were marked on a continuous line allowing non-integer numbers. In part 2, participants identified which learning resources they used during the preparation period. The questionnaire includes a list of resources from which participants could select more than one. In part 3, participants had to express a level of agreement on a five-point Likert scale, with level 1 meaning 'strongly disagree' and level 5 meaning 'strongly agree'. Statements related to how the competition impacted their motivation to learn physics and science were given in the form of a table, and respondents were asked to mark one of five levels. Part 4 referred to how working in a group impacted accomplishing the main task; as in part 3, responses were given on a five-point Likert scale.

The mentor questionnaire comprised 11 questions phrased similarly to those in the participant questionnaire. Mentors expressed their level of agreement on a five-point Likert scale with the same form and meaning as in parts 3 and 4 of the participant questionnaire. We decided to include fewer questions in the mentor questionnaire because we assumed that they would respond with full understanding and caution. Therefore, we limited the number of questions addressing the same item. The mentor questionnaire is given in full in "Appendix 2".

After the Grand Finale, a semi-structured interview was conducted with selected jury members who are familiar with the school curricula. The interview comprised three sets of questions, the first related to students' knowledge and contraption preparation, the second related to group work, and the third related to any unusual phenomena or solutions that the jury members could recall ("Appendix 3").

\section{Rationale for selecting questionnaires}

We must sketch some limitations of the study. First, we used our own questionnaires. We are aware that it would have been methodologically more accurate to use a previously developed and validated test, but the uniqueness of the Chain Experiment competition meant that the questionnaires had to be developed from scratch.

Second, rather that measuring learning and improvement directly, we assessed participant and mentor perceptions of those aspects. We did this because we decided that there is no reliable, usable tool for measuring the researched items, this being because participation in the competition lasts for several months and any 'objective' measure would be influenced by several other factors, such as current school materials. Therefore, we had to rely on participants' perception of changes, i.e. how participating in the Chain Experiment influenced particular aspects (knowledge, motivation and soft skills). Nevertheless, we expect that participants and mentors were able to separate the influence of the Chain Experiment experience from other factors affecting the participants' learning during the school year. Unfortunately, the schedule of the Chain Experiment 
competition made impossible interviewing all the participants. The Grand Finale took place two to three weeks before the end of the school year, leaving insufficient time to visit schools all over the country (note that there were close to 500 participants).

Third, we collected questionnaires during the Grand Finale, after the competition and just before the jury announced the winners. The answers given then were not influenced by the joy of winning or the bitterness of losing. However, the results could have been influenced somehow by the atmosphere of the Grand Finale event as a whole.

Finally, this research was designed to investigate whether participating in the competition affects the development of participants' soft skills, motivation and knowledge. Moredetailed research would be needed to investigate the subtleties of how the Chain Experiment competition influences those abilities as well as in depth studies how certain pedagogical strategies within PBL, collaborative learning and gamification contributed to observed outcomes. Nevertheless, students' and mentors' opinions on the subject could provide a good starting point for that research.

\section{Data analysis}

To compare the questions in both questionnaires directly, we introduced a single scale for all questions even though two different Likert scales were used. Thus, the levels from 1 to 5 used in parts 3 and 4 of the participant and mentor questionnaires were transformed to the same range as in part 1 of the participant questionnaire, i.e. from -5 to 5 . The transformation was done using

$$
y=2.5 x-7.5
$$

where $x$ is the level of agreement given on the five-point Likert scale and $y$ is the modified level of agreement expressed on the 11-point Likert scale from -5 to 5 . In this way, a level of agreement marked as 1 on the five-point Likert scale was transformed to -5 on the 11-point Likert scale, 3 became 0, and so on.

\section{Participant questionnaire}

In this questionnaire, participants reflected on and self-assessed how the Chain Experiment competition influenced the aspects of their development described in the five assumptions of this study (Table 3). The coherency of participants' answers parcelled into those assumptions was verified and the results are presented in Table 4. To decide whether the assumptions are statistically consistent, we calculated Cronbach's alpha for each one. For each question group, this factor always exceeds 0.7 and each question has a positive discriminative power, meaning that the questions are correlated positively. Additionally, discriminating any particular question does not increase Cronbach's alpha. All these factors confirm that the assumptions were prepared and then parcelled adequately.

The questions in part 2 (i.e. those asking about the sources of participants' knowledge) were analysed separately. The sum of the share of answers expressed as a percentage in each age category exceeds $100 \%$ because each participant was allowed to select more than one answer. 
Table 4 The five assumptions parcelled into questions from the participant questionnaire (Appendix 1)

\begin{tabular}{|c|c|c|c|c|c|c|c|c|c|c|c|c|c|c|}
\hline \multicolumn{3}{|c|}{$\begin{array}{l}\text { A1. Cronbach's } \\
\text { alpha: } 0.887\end{array}$} & \multicolumn{3}{|c|}{$\begin{array}{l}\text { A2. Cronbach's } \\
\text { alpha: } 0.811\end{array}$} & \multicolumn{3}{|c|}{$\begin{array}{l}\text { A3. Cronbach's } \\
\text { alpha: } 0.779\end{array}$} & \multicolumn{3}{|c|}{$\begin{array}{l}\text { A4. Cronbach's } \\
\text { alpha: } 0.733\end{array}$} & \multicolumn{3}{|c|}{$\begin{array}{l}\text { A5. Cronbach's } \\
\text { alpha: } 0.735\end{array}$} \\
\hline QN & DP & EX & QN & DP & EX & $\mathrm{QN}$ & DP & EX & QN & DP & EX & QN & DP & EX \\
\hline Q3.5 & 0.65 & 0.87 & Q1.1 & 0.60 & 0.78 & Q1.2 & 0.57 & 0.80 & Q1.4 & 0.4 & 0.63 & Q1.7 & 0.54 & 0.70 \\
\hline Q3.6 & 0.68 & 0.87 & Q1.3 & 0.57 & 0.78 & Q3.2 & 0.67 & 0.67 & Q3.1 & 0.45 & 0.53 & Q3.7 & 0.56 & 0.63 \\
\hline Q4.1 & 0.70 & 0.87 & Q1.5 & 0.62 & 0.77 & Q3.3 & 0.67 & 0.66 & Q3.4 & 0.50 & 0.47 & Q3.8 & 0.59 & 0.61 \\
\hline Q4.2 & 0.70 & 0.87 & Q1.6 & 0.66 & 0.77 & & & & & & & & & \\
\hline Q4.3 & 0.62 & 0.88 & Q1.8 & 0.49 & 0.81 & & & & & & & & & \\
\hline Q4.4 & 0.59 & 0.88 & Q3.5 & 0.42 & 0.81 & & & & & & & & & \\
\hline Q4.5 & 0.67 & 0.87 & Q3.6 & 0.54 & 0.79 & & & & & & & & & \\
\hline Q4.6 & 0.68 & 0.87 & & & & & & & & & & & & \\
\hline
\end{tabular}

For each question (QN), its discriminative power (DP) and Cronbach's alpha after exclusion (EX) were calculated

\section{Mentor questionnaire}

The analysis of the mentor questionnaire was similar to that of the participant questionnaire. Questions were asked about participants' development regarding soft skills and scientific knowledge, as well as the motivational role of participating in the competition. Next, Cronbach's alpha was calculated for each set of questions to verify the consistency, then (a) the normality of the distribution was determined using the Shapiro-Wilk test and (b) whether the means or medians were equal to zero was examined using $t$ test and Wilcoxon's test, respectively.

Assumption 2 involved one question about communication skills, this being because a mentor can notice progress in this particular ability very easily. Assumptions A1m (when the ' $\mathrm{m}$ ' refers to the mentor questionnaire), A3m, A4m and A5m were formulated in the same way as in the analysis of the participant questionnaire. Additionally, two questions that asked about knowledge acquisition beyond the curriculum (Q2m) and students' grades in physics or science while participating in the competition (Q11m) were chosen for separate analysis. Neither of those aspects could be evaluated by students themselves, and also they provide more-specific evaluation of students' development.

Each assumption, parcelled into a set of questions, is described in Table 5. Cronbach's alpha for assumptions A1m, 3-5m exceeds 0.7 , thereby showing that the questions were selected properly. This factor was not calculated for assumption A2m because it corresponded to one question only.

Table 5 The five assumptions parcelled into questions from the mentor questionnaire (Appendix 2)

\begin{tabular}{lll}
\hline Hypothesis & Questions for hypothesis & Cronbach's alpha \\
\hline A1m & Q4m, Q8m & 0.72 \\
A2m & Q7m & - \\
A3m & Q5m, Q6m & 0.71 \\
A4m & Q1m, Q2m, Q10m, Q11m & 0.80 \\
A5m & Q3m, Q9m & 0.76 \\
\hline
\end{tabular}

For each assumption, Cronbach's alpha was calculated 


\section{Semi-structured interviews}

The interview data were analysed qualitatively by thematic analysis. Statements by jury members about the Chain Experiment were analysed by three independent researchers, and their findings were gathered to find common patterns across the datasets.

\section{Results}

\section{Participant questionnaire}

All five assumptions were analysed in three age categories created according to the educational levels of the participants. Group 1 includes PS students in education grades K1-K6, group 2 includes L-SS students in K7-K9, while group 3 was the oldest analysed group and consists of HS students in K10-K12. No family category was included in the analysis because of the wide diversity in participants' age, knowledge and experience inside each group in that category.

The data distribution was analysed using the Shapiro-Wilk test. In further analysis, when required, we used the mean value for normally distributed data and the median in case of non-normal distribution. In the next step, we asked whether there was any change in each of the examined assumptions. To check this, the mean or median was compared with the zero level. $t$ Test was performed in cases of normal distribution, otherwise Wilcoxon's test was performed. If the corresponding result was negative (i.e. $p<0.05$ ), the aforementioned presumption is incorrect and a significant difference in the investigated assumption is observed.

It is clear from Table 6 that in each age group, there is a significant difference relating to all the tested assumptions. This crucial finding allowed us to conduct further tests aimed at determining whether the answers given in the three age groups were significantly different. If participants' opinions had a normal distribution, analysis of variation (ANOVA) was conducted. Otherwise, the Kruskal-Wallis test was used to determine whether distinct age groups responded differently. The final part of the statistical comparison was post hoc analysis. Assumptions with a normal distribution of answers were analysed using Fisher's LSD test. In cases of non-normal distribution in one assumption, Dunn's test was used to compare opinions in the three age groups.

Table 6 Results of $t$ test (A2) and Wilcoxon's test (A1, A3, A4 and A5), which assume that the mean/ median value of the answers in each group is zero

\begin{tabular}{|c|c|c|c|c|c|}
\hline \multirow[t]{3}{*}{ Category } & $\begin{array}{l}\text { Assumption } 1 \\
H_{0}: \text { median }=0\end{array}$ & Assumption 3 & Assumption 4 & Assumption 5 & \multirow{3}{*}{$\begin{array}{l}\text { Assumption } 2 \\
H_{0}: \text { mean }=0 \\
t \text { test } \\
p \text { value }\end{array}$} \\
\hline & \multicolumn{4}{|l|}{ Wilcoxon's test } & \\
\hline & $p$ value & & & & \\
\hline Primary school & $<0.001$ & $<0.001$ & $<0.001$ & $<0.001$ & $<0.001$ \\
\hline Lower-secondary school & $<0.001$ & $<0.001$ & $<0.001$ & $<0.001$ & $<0.001$ \\
\hline High school & $<0.001$ & $<0.001$ & $<0.001$ & $<0.001$ & $<0.001$ \\
\hline Total & $<0.001$ & $<0.001$ & $<0.001$ & $<0.001$ & $<0.001$ \\
\hline
\end{tabular}


Assumption 1 Working in groups could increase participants' motivation and helps them to solve problems.

This assumption was parcelled into eight questions (Q3.5, Q3.6, Q4.1, Q4.2, Q4.3, Q4.4, Q4.5, Q4.6; see Table 3). For this group, Cronbach's alpha was calculated as 0.887 and each question had positive discriminative power. The Shapiro-Wilk test showed that the distribution of answers was non-normal, thus analysis of medians was performed. The Kruskal-Wallis test and post hoc analysis showed that HS and PS students gave more positive opinions than did L-SS students. Table 10 shows that the first assumption has the widest range of answers, from -5 to 5 . Nevertheless, after analysing the lower quartiles combined with data from Table 7 , we conclude that each age group had a general positive attitude to this assumption.

Assumption 2 Participating in the competition could have a positive impact on participants' soft skills.

This assumption was tested with seven questions (Q1.1, Q1.3, Q1.5, Q1.6, Q1.8, Q3.5, Q3.6; see Table 3) for which Cronbach's alpha equals 0.811. The answers had a normal distribution, thus the mean values in each group were analysed. As shown in Table 8, significant positive opinions can be observed in all examined groups. Further ANOVA and Fisher's LSD showed that HS students have significantly more-positive opinions about assumption 2 than do L-SS participants, with a difference of 0.55 between the means in these categories. Because the possible range of answers was from -5 to 5 , their lower limit is quite high, from -1.71 in L-SS up to -0.29 in HS.

Assumption 3 Participating in the competition could increase participants' interest in physics and science.

This assumption was parcelled into three questions (Q1.2, Q3.2, Q3.3; see Table 3). Cronbach's alpha for this group was 0.779 and the discriminative power of each question was positive. The distribution of answers was non-normal, so the Kruskal-Wallis test and the Dunn test (as post hoc analysis) were conducted. The statistical comparison presented in Table 9 shows that L-SS students rated Assumption 3 significantly lower (median: 1.83) than did those at PS (median: 3.50) and HS (median: 2.67). The total range of answers was quite wide, from -4.33 in the second age category up to 5 in all groups. Moreover, in each category we found a generally positive trend in participants' answers.

Assumption 4 Participating in the competition could increase participants' scientific knowledge.

This assumption was parcelled into three questions (Q1.4, Q3.1, Q3.4; see Table 3). Positively correlating scores have a Cronbach's alpha equal to 0.733 and positive discriminative power. The non-normality of the distribution of answers imposed further analysis of medians. To investigate differences between participants' age groups, Kruskal-Wallis and post hoc analyses were performed. Table 10 clearly shows that PS participants had significantly more-positive opinions than did L-SS and HS contestants. The lower limit of answers is -3.33 in every group, but there are significant positive opinions in every category. 
Table 7 Results of analysing Assumption 1

\begin{tabular}{|c|c|c|c|c|c|c|c|c|c|}
\hline \multirow[t]{2}{*}{ Category } & \multicolumn{8}{|c|}{$\begin{array}{l}\text { Assumption } 1 \text {. Working in groups could increase participants' moti- } \\
\text { vation and helps them to solve problems }\end{array}$} & \multirow[t]{2}{*}{$p^{*}$} \\
\hline & No. & Mean & SD & Median & Min & $\operatorname{Max}$ & $\begin{array}{l}\text { Lower } \\
\text { quartile }\end{array}$ & $\begin{array}{l}\text { Upper } \\
\text { quar- } \\
\text { tile }\end{array}$ & \\
\hline Primary school (PS) & 122 & 2.3 & 2.23 & 2.5 & -4.06 & 5 & 1.56 & 4.06 & \multirow{4}{*}{$\begin{array}{l}0.001 \\
\mathrm{HS}>\mathrm{L}-\mathrm{SS}\end{array}$} \\
\hline $\begin{array}{l}\text { Lower-secondary } \\
\text { school (L-SS) }\end{array}$ & 236 & 1.65 & 2.22 & 1.88 & -5 & 5 & 0.31 & 3.12 & \\
\hline High school (HS) & 95 & 2.76 & 1.94 & 3.12 & -3.44 & 5 & 1.88 & 4.06 & \\
\hline Total & 453 & 2.04 & 2.2 & 2.5 & -5 & 5 & 0.62 & 3.75 & \\
\hline
\end{tabular}

$p^{*}$ was calculated using the Kruskal-Wallis test and post hoc analysis

Table 8 Results of analysis Assumption 2

\begin{tabular}{lccccccccc}
\hline Category & \multicolumn{8}{l}{$\begin{array}{l}\text { Assumption 2. Participation in the competition could have a positive } \\
\text { impact on students' soft skills }\end{array}$} \\
\cline { 2 - 10 } & No. & Mean & SD & Median & Min & Max & $\begin{array}{l}\text { Lower } \\
\text { quartile }\end{array}$ & $\begin{array}{l}\text { Upper } \\
\text { quartile }\end{array}$ \\
& 122 & 2.13 & 1.3 & 2.07 & -1.07 & 4.14 & 1.29 & 3.21 & 0.017 \\
\hline $\begin{array}{l}\text { Primary school (PS) } \\
\text { Lower-secondary }\end{array}$ & 236 & 1.72 & 1.46 & 1.5 & -1.71 & 5 & 0.86 & 2.71 & L-SS $<$ HS \\
$\quad$ school (L-SS) & 95 & 2.27 & 1.33 & 2.57 & -0.29 & 5 & 1.21 & 3.21 & \\
$\begin{array}{l}\text { High school (HS) } \\
\text { Total }\end{array}$ & 453 & 1.93 & 1.41 & 1.93 & -1.71 & 5 & 0.93 & 3 & \\
\hline
\end{tabular}

$p^{*}$ was calculated using the ANOVA and Fisher's LSD test

Table 9 Results of analysing Assumption 3

\begin{tabular}{lrllllllll}
\hline Category & \multicolumn{8}{l}{$\begin{array}{l}\text { Assumption 3. Participating in the competition could increase par- } \\
\text { ticipants' interest in physics and science }\end{array}$} & $p^{*}$ \\
\cline { 2 - 10 } & No. & Mean & SD & Median & Min & Max & $\begin{array}{l}\text { Lower } \\
\text { quartile }\end{array}$ & $\begin{array}{l}\text { Upper } \\
\text { quartile }\end{array}$ & \\
& 122 & 2.67 & 2.18 & 3.5 & -3.33 & 5 & 1.33 & 4.33 & 0.001 \\
Primary school (PS) & 236 & 1.54 & 2.27 & 1.83 & -4.33 & 5 & 0 & 3.5 & PS $>$ L-SS \\
$\begin{array}{l}\text { Lower-secondary } \\
\text { school (L-SS) }\end{array}$ & 95 & 2.26 & 1.69 & 2.67 & -2.33 & 5 & 1.0 & 3.5 & \\
$\begin{array}{l}\text { High school (HS) } \\
\text { Total }\end{array}$ & 453 & 1.93 & 2.17 & 2.33 & -4.33 & 5 & 0.67 & 3.5 & \\
\hline
\end{tabular}

$p^{*}$ was calculated using the Kruskal-Wallis test and post hoc analysis 
Table 10 Results of analysing Assumption 4

\begin{tabular}{|c|c|c|c|c|c|c|c|c|c|}
\hline \multirow[t]{2}{*}{ Category } & \multicolumn{8}{|c|}{$\begin{array}{l}\text { Assumption 4. Participating in the competition could increase partici- } \\
\text { pants' scientific knowledge }\end{array}$} & \multirow[t]{2}{*}{$p^{*}$} \\
\hline & No. & Mean & SD & Median & Min & $\operatorname{Max}$ & $\begin{array}{l}\text { Lower } \\
\text { quartile }\end{array}$ & $\begin{array}{l}\text { Upper } \\
\text { quartile }\end{array}$ & \\
\hline Primary school (PS) & 122 & 2.98 & 1.8 & 3.17 & -3.33 & 5 & 2.67 & 4.33 & \multirow{4}{*}{$\begin{array}{c}0.001 \\
\mathrm{PS}>\mathrm{HS}, \\
\quad \mathrm{L}-\mathrm{SS}\end{array}$} \\
\hline $\begin{array}{l}\text { Lower-secondary } \\
\text { school (L-SS) }\end{array}$ & 236 & 1.92 & 2.04 & 2.33 & -3.33 & 5 & 0.83 & 3.5 & \\
\hline High school (HS) & 95 & 2.32 & 1.62 & 2.67 & -3.33 & 5 & 1.5 & 3.33 & \\
\hline Total & 453 & 2.23 & 1.94 & 2.67 & -3.33 & 5 & 1.17 & 3.5 & \\
\hline
\end{tabular}

$p^{*}$ was calculated using the Kruskal-Wallis test and post hoc analysis

Table 11 Results of analysing Assumption 5

\begin{tabular}{|c|c|c|c|c|c|c|c|c|c|}
\hline \multirow[t]{2}{*}{ Category } & \multicolumn{8}{|c|}{$\begin{array}{l}\text { Assumption 5. Participating in the competition could motivate par- } \\
\text { ticipants to further work and undertake new scientific challenges }\end{array}$} & \multirow[t]{2}{*}{$p^{*}$} \\
\hline & No. & Mean & SD & Median & Min & $\operatorname{Max}$ & $\begin{array}{l}\text { Lower } \\
\text { quartile }\end{array}$ & $\begin{array}{l}\text { Upper } \\
\text { quar- } \\
\text { tile }\end{array}$ & \\
\hline Primary school (PS) & 122 & 2.96 & 1.92 & 3.5 & -3.33 & 5 & 2.67 & 4.33 & \multirow{4}{*}{$\begin{array}{l}0.004 \\
\text { PS, } \\
\quad \text { HS }>\text { L-SS }\end{array}$} \\
\hline $\begin{array}{l}\text { Lower-secondary } \\
\text { school (L-SS) }\end{array}$ & 236 & 2.25 & 1.98 & 2.67 & -4 & 5 & 0.83 & 3.83 & \\
\hline High school (HS) & 95 & 3.05 & 1.41 & 3.33 & 0 & 5 & 2.42 & 4.25 & \\
\hline Total & 453 & 2.58 & 1.89 & 3.17 & -4 & 5 & 1.5 & 4 & \\
\hline
\end{tabular}

$p^{*}$ was calculated using the Kruskal-Wallis test and post hoc analysis

Assumption 5 Participating in the competition could motivate participants to further work and undertake new scientific challenges.

This assumption was also tested using three questions (Q1.7, Q3.7, Q3.8; see Table 3). Cronbach's alpha calculated for this set was 0.735 , which indicates its reliability. Further analysis of non-normally distributed answers was performed in the same way as previously. Table 11 shows that answers given by students attending PS and HS were very similar to one another (medians 3.5 and 3.33, respectively) and significantly higher than those given by L-SS students. Note also that at zero, the lower limit for the answers given by HS students' was relatively high. This shows that no participant in this category had a negative opinion of this assumption. The lower quartiles being greater than zero confirms a clear positive opinion in every age group.

\section{Participants' answers in age categories}

The final part of analysing the participants' assumptions is to compare them among age categories. The first overall conclusion is that the lower quartiles of answers are mostly greater than or equal to zero (L-SS students, H3). Figure 2 shows that the medians and means of answers are also greater than zero, indicating that positive opinions were given 
in every category and for all questions. PS students rated Assumptions 1 and 4 higher than other assumptions, with a median greater than 3. Furthermore, this age category had the most-positive opinions about all examined items. HS students rated all assumptions slightly lower but still positively, with the highest medians being those for Assumptions 1 and 3; the medians are still high and greater than 3, but the upper quartiles are only just above 4 . Like the PS students, the L-SS ones rated Assumptions 1 and 4 most positively. However, compared to the other categories, the L-SS medians and quartiles are the lowest in all the examined items. Also, a wider distribution of answers can be observed. While the lower quartiles for the HS and PS opinions are greater than 1, the same statistical parameters are lower for L-SS ones. As is clear from Fig. 2, the ratings of each assumption depend on age category, differing in distribution width, median and mean. Combining all the analysed age groups, the lowest ratings can be observed for Assumptions 2 and 5.

\section{Sources of students' knowledge}

The final part of the analysis considers the sources of the acquired knowledge and learning materials that participants used while preparing for the competition. Participants could choose multiple options to specify all possible methods by which they found the information that was needed to build the device. As Fig. 3 shows, the most popular source in every group was the internet. This was followed by school classes, which proved to be useful for L-SS and HS students. For PS participants, consultations with parents were more important, with school classes relegated to third place. Participants in this category had extra-curricular lessons with the mentor and used auxiliary books more frequently than did other contestants. Note also that HS students looked to their older siblings for answers more often than did PS and L-SS students, while at the same time they found school classes to be an important source of knowledge. Moreover, in this age group, participants were more likely to search for inspiration in scientific videos. Even though not related directly to the RQs, these results are indirect proof that the Chain Experiment promotes motivation and engagement, as well as the acquisition of scientific knowledge to realize the competition task.

\section{Mentor questionnaire}

The mentors' answers were analysed together without separation into the different age categories of the participants. Normality determination using the Shapiro-Wilk test showed that all assumptions and additional questions had non-normal distribution. Thus, the following step consisted of Wilcoxon's test, in which we assume that the median of answers is equal to zero. The values presented in Table 12 clearly show a significant difference from zero (meaning any change due to the examined assumption) in the case of every assumption and the two questions that were analysed separately.

The mentor questionnaire was subjected to a basic statistical analysis, resulting in the means, medians, standard deviations, total range of answers and values of the first and third quartiles presented in Table 13. Note that assumptions A1m and A2m achieved the highest scores; the lowest answer was 2.5 in both cases. Similarly, assumptions A4m and A5m had the lowest answer (1.25) and the median values (for both) reached almost 5. This suggests that participation in the Chain Experiment competition has a positive impact on better communication and group-work abilities, and mentors think that it may increase participants' scientific knowledge and motivate them to take part in the same or other scientific 
competitions. Moreover, the high median for A3m (3.75) confirms that the Chain Experiment competition particularly increases interest in physics and science. By analysing questions Q2m and Q11m separately, we conclude that participants from all age groups, while preparing their contraption, mastered the curriculum and gained better scores in physics than before participation. Here, similarly to all the analysed assumptions, the medians of answers given by mentors reached 5, i.e. the highest value.

Comparing both questionnaires shows that mentors' answers are very similar to participants' opinions. Mentors think that their students developed their soft skills and acquired new knowledge. Note that students seem to go beyond the standard curriculum, learning about phenomena that are not taught in school at their educational level. Moreover, the mentors noticed a definite improvement in terms of school grades in physics or science, which shows that participating in the Chain Experiment competition has a noticeable impact on everyday school work. The motivational effect of participation was also highlighted by the mentors, as was the encouragement to learn physics or science side by side, with increasing interest in these subjects. In the end, the group-work format was also rated positively by the mentors.

\section{Semi-structured interviews}

After the Grand Finale, jury members articulated their observations in a semi-structured interview ("Appendix 3"). The first set of questions was related to complexity of students' contraptions and students' knowledge and abilities to explain them in terms of physics and science laws. Each interviewed person stressed that almost all contraptions were unique. PS students used the simplest phenomena, but their contraptions were graphically refined. Nevertheless, jury members stressed that "the children tried to explain all the phenomena, sometimes with words that they did not fully understand, but there was a visible passion in their eyes". Note that because PS students do not have physics as a separate subject, each solution is in principle beyond the curriculum. The youngest participants usually worked and explained the contraption operation together, sometimes answering the jury's questions simultaneously. Coriolis force appeared for the first time in this category.

In the L-SS category, the jury easily distinguished two types of contraptions: very simple ones that used basic phenomena, mainly from kinematics (e.g. slipways) and highly advanced ones that used phenomena from various fields (e.g. electricity, magnetism, optics). Naturally, the first group did not delight the jury; the participants could usually describe the operation of the contraption, but they were unable to answer any deeper questions. Fortunately, this group was a minority. The creators of more-advanced contraptions in this age span reached for phenomena from various fields of physics, usually trying to use as many as they could fit in the size limitations of the contraption. In this age category more often than in the others, a group leader was observable, but it varied from group to group.

The jury members deemed the contraptions of HS participants to be the most sophisticated. They usually focused on only a few branches of physics, but within them they developed some surprising uses; for example, not only building a magnetic gun but also making the steel ball levitate. So even though participants used phenomena that they had been taught in school, the specific applications of those phenomena significantly exceed expectations. After assessing participants' work, the jury emphasized that often the division of tasks was visible: "During the explanation, each team member could describe the whole contraption, but different members explained different details in depth. Further conversation showed that almost always the person explaining an idea had been its trailblazer.". The 
important point is that most participants could enter into a substantive discussion with the jury about not only the utilized phenomenon (e.g. magnetic gun) but also entire general units (e.g. magnetism, dynamics). In this category, elements of robotics and programming also appear.

The family category usually comprised groups of friends of different ages, often parents with children. The scientific level of the contraptions differed considerably, but the greatest value was in passion being transferred from parents to their children. "It was really nice to see the parental pride when her/his child explained the operation of the device that they had created together." In this group, common work was the most obvious and easy to observe.

In summary, although the levels of contraption and participant involvement varied among the categories, the opinions of the jury members were generally very positive. They stressed that while it demanded additional time and work from participants, participants had fun working in a scientific exercise. Let us quote a few responses as examples:

It is difficult to highlight a particularly memorable solution because all the experiments are unique. If I had to choose a creative solution that I remember especially, in the last edition of the competition there was a fantastic mobile, double-sided machine that half changed its appearance completely. This solution was extremely effective and very interesting.

You can see immediately whether someone has devoted a lot of time or this was a last-minute project. With the machines that required a long preparation time and were carefully made and thought out, usually those participants explained very precisely what they meant. It shows at a glance whether someone came up with the idea at the last moment or worked on the concept for longer.

It was clear that many teams were applying mechanisms that were beyond their school curriculum. Those students were also exhibiting a deep understanding of the physical basics of the used phenomena. Even if they used a "standard curriculum" phenomenon, it was applied in a non-standard context, i.e. not in the way in which it is taught in school. It was clear that those students were passionate about science.

\section{Discussion}

In this study, we examined whether participating in the Chain Experiment competition has a positive influence on various aspects of participants' motivation and skills. For this purpose, we analysed semi-structured interviews with jury members and two questionnaires given to the participants and their mentors after the Grand Finale of the fifth edition of the competition. Positive opinions were recognized in the three designated age groups (PS, L-SS and HS). We will discuss our findings in relation to the five posed RQs.

We began by examining whether the Chain Experiment competition, and particularly the aspect of group work, is perceived positively by its participants and mentors. We formulated this in Assumption 1, which was tested in two separate, participant and mentor, questionnaires. We found that students in all age categories claimed that group work in the first instance encouraged them to participate in the competition; in the second instance, it simplified the learning process, facilitated problem solving and stimulated new ideas; in the third instance, it decreased stress during the task. This is in line with the literature, which shows that collaborative group work can stimulate greater achievements (Barkley et al. 2014). Also, the role of the gamification approach, which can increase engagement (Dicheva 
et al. 2015; Sadler et al. 2013), helps in problem solving. The mentors' opinions were in line with those of the participants. Also, jury members expressed similar opinions and claimed that general cooperation between team members was observed. This might be an important factor in this discussion, because working with others on the same problem helps with overcoming failures and learning from each other. The Chain Experiment project usually lasts for a few months and requires new ideas to be tested, discussed and presented and/or defended to others. Working on the same problem with colleagues, together with multiple possible arguments about how to design the contraption, naturally leads to soft skills.

Working on a common goal naturally engages soft skills, the possible development of which we verified in the second RQ. Since its first edition, the Chain Experiment has been developed as a team competition that requires a cooperating team. The approach used in this competition has been appreciated by corporations, which have suggested that employees should participate in the Chain Experiment (Susman et al. 2017). In all age categories, this assumption was rated positively by both participants and mentors. The jury members could not verify the development of soft skills, but they reported that participants could describe and present their device coherently, being able to defend their own ideas during discussions with the jury.

Note that in the definition of soft skills, we focused also on the ability to search for information. This was verified partially by a question about the sources of knowledge. While looking for ideas about how to create their own contraption, participants were searching within a variety of sources, including those not obligatory in school, i.e. internet, books, scientific movies and discussions with other people. Altogether, this suggests that participating in the Chain Experiment competition might have a positive influence on the soft skills of its participants.

From a theoretical perspective, we postulated that the form of the Chain Experiment intertwines three approaches, namely gamification, PBL and collaborative learning. While we acknowledge that further research is required in order to find specific contribution each of them have on chain experiment outcomes, the current literature could give us a hint for discussing current results. Each of these approaches separately stimulates soft-skills improvement (Dochie et al. 2017; Idrus and Abdullah 2018; Trevor et al. 2020), and thus it is not very surprising that their combination is also beneficial, as shown by the present study. Among the three approaches, it was shown that collaborative learning helps in building more-effective oral communication (Davidson and Major 2014; Springer et al. 1999). It might be important to add that assumption 2 was rated most positively by HS students, who already had better scientific knowledge than the other groups. This may be a result of implementing the PBL approach, which can develop complex "hard" and soft skills (Albanese and Mitchell 1993; Blumenfeld et al. 1991; Vernon and Blake 1993; Gallagher 1997). It can also help in many further activities, including finding employment, when these two types of skills are very often required. In summary, we suggest that the Chain Experiment has the potential to develop participants' soft skills, but further studies are required to be sure.

The problem that participants face in the Chain Experiment is real and open ended. The final well-operating contraption could be constructed in an infinite number of ways, thereby stimulating the scientific curiosity of participants. The results obtained from analysing Assumption 3 show that participating in the Chain Experiment may increase participants' interest in science. This is also evident in the students' contraptions, in which they used many phenomena that are not taught in schools. The jury members stressed that teams that had constructed such solutions described them with huge commitment and passion.

This is the aim of all educational approaches, all of which could be cited here. However, we would like to focus on gamification in particular because the element of rivalry with 

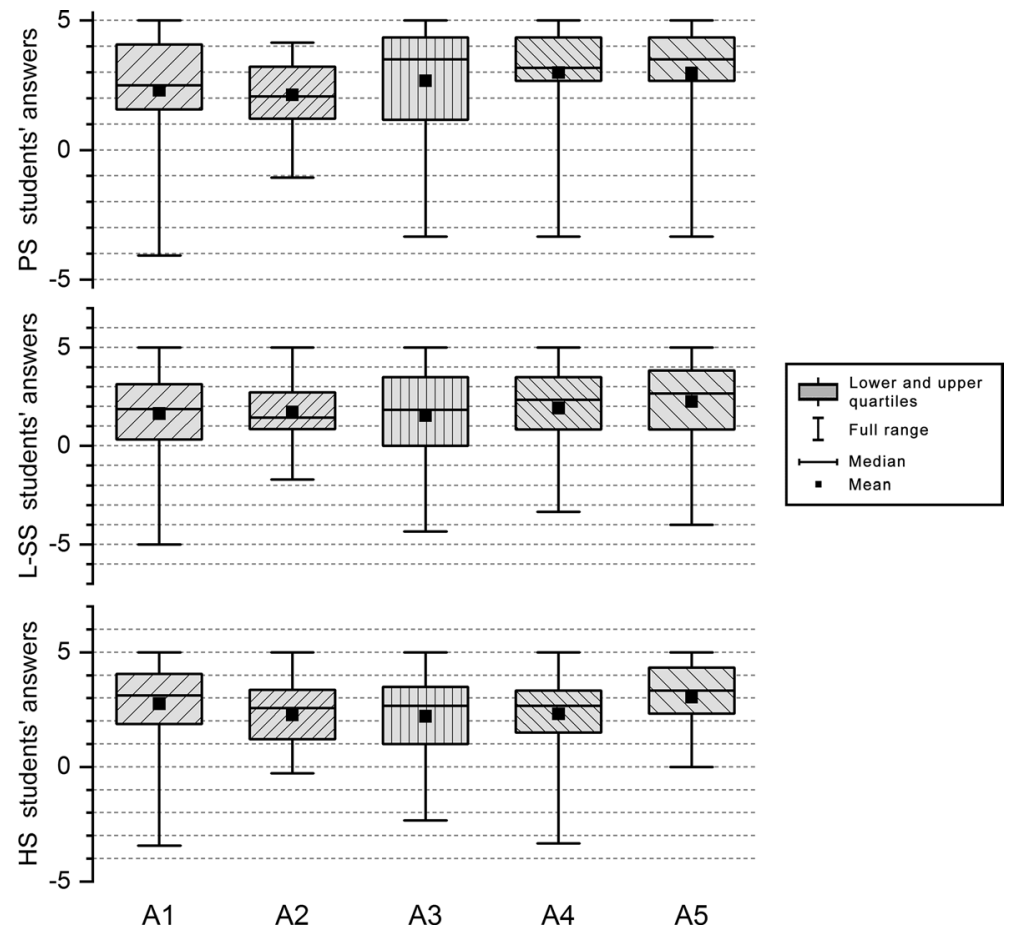

Fig. 2 Box plots of participants' answers in each Assumptions (A1-A5). The first row pertains to primary school (PS) students, the second row to lower-secondary school (L-SS) students and the third row to high school (HS) students. The borders of each box mark the first and third quartiles, while the horizontal line and black square present the median and mean, respectively. The whiskers on the boxes signify the full range of answers

Fig. 3 Sources of participants' knowledge in the PS, L-SS and $\mathrm{HS}$ age categories

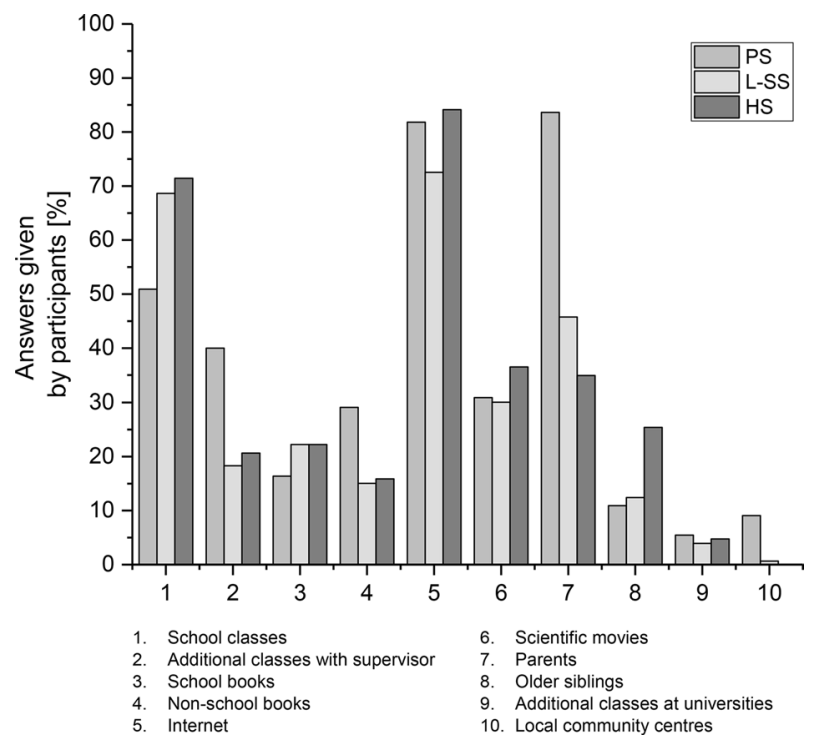


Table 12 Results of Wilcoxon's test, assuming the median of answers in each group (hypotheses or questions) is equal to 0

\begin{tabular}{llllllll}
\hline Hypothesis or question & H1m & H2m & H3m & H4m & H5m & Q2m & Q11m \\
\hline $\begin{array}{l}H_{0}: \text { median }=0 ; p \text { value (Wilcoxon } \\
\text { test) }\end{array}$ & $<0.001$ & $<0.001$ & $<0.001$ & $<0.001$ & $<0.001$ & $<0.001$ & $<0.001$ \\
\hline
\end{tabular}

Table 13 Results of analysing all mentors' hypotheses and two separate questions

\begin{tabular}{lcccccccc}
\hline $\begin{array}{l}\text { Hypothesis/ } \\
\text { question }\end{array}$ & No. & Mean & SD & Median & Min & Max & Lower quartile & Upper quartile \\
\hline H1m & 73 & 4.32 & 0.74 & 4.38 & 1.25 & 5.00 & 4.38 & 5.00 \\
H2m & 73 & 3.87 & 1.29 & 3.75 & 0.00 & 5.00 & 3.13 & 5.00 \\
H3m & 73 & 4.32 & 0.88 & 5.00 & 1.25 & 5.00 & 3.75 & 5.00 \\
H4m & 73 & 4.40 & 1.00 & 5.00 & 2.50 & 5.00 & 3.75 & 5.00 \\
H5m & 73 & 4.28 & 1.14 & 5.00 & 2.50 & 5.00 & 2.50 & 5.00 \\
Q2m & 73 & 4.73 & 0.89 & 5.00 & 0.00 & 5.00 & 4.25 & 5.00 \\
Q11m & 73 & 4.32 & 1.63 & 5.00 & 0.00 & 5.00 & 4.25 & 5.00 \\
\hline
\end{tabular}

other players pushed participants to develop increasingly creative ideas. Many authors have shown that competition-like activity, during which students work on a task in competition with other contestants, can have a positive motivational effect (Ozturk and Debelak 2008; Thrasher 2008; Wankat 2005). Integrating elements from a game-like approach with cooperative learning multiplies the motivational effect of these methods (Kapitanoff 2009; Hanus and Fox 2015) and is effective at improving students' retention of knowledge.

Interest in science is usually connected with gaining scientific knowledge, which was our fourth RQ. We were unable to verify it directly, so instead we relied on the opinions of participants and mentors and the observations of jury members. However, all of those sources were consistent. According to the participants and their mentors, the challenge given by the competition required the acquisition of new knowledge (A4, A4m). A similar aspect was found in the statements of the jury members, namely that participants often used scientific phenomena that went beyond the school curriculum and were able to explain them. This is in line with the collaborative learning method that is used by participants during competitions and that has been shown to promote learning, increase retention of given material and help students to achieve more (Barkley et al. 2014; Kuo et al. 2012; Schellens and Valcke 2005). From analysing the mentors' answers in more detail, the expectation is that participants will begin to get better test results and marks in physics (science) at school (Q11m). This could be due to the competition task itself, which requires acquisition of not only technical knowledge (i.e. how to build it) but also scientific knowledge (i.e. how and why it works). This is an important statement of design education and notably PBL, in which students should acquire new knowledge to solve the problem. Gaining knowledge was classified as one of the main effects of the PBL approach, which has been proven to lead to better educational and academic achievements (Evensen 2000; Hmelo-Silver 2004; Lee and Lim 2012). We suppose that the positive effect on students' knowledge that we observed was multiplied by the gamification approach, which is known to increase both learning efficiency and participant motivation (Banfield and Wilkerson 2014; Dicheva et al. 2015; Seaborn and Fels 2015), specifically in areas perceived by 
students as being particularly difficult, such as mathematics or science. All the data gathered in relation to RQ4 suggest that the Chain Experiment seems to be an interesting way for transferring knowledge to students and promoting their interest in science. However, the answer to the question "how?" rather than "if?" will require further studies.

Finally, in RQ5 we asked whether the Chain Experiment could increase students' motivation for further learning. To assess it, we analysed the answers given by both participants and mentors gathered in A5 and A5m. Their opinions suggest that participating in the Chain Experiment (a) motivates further learning because how the competition task is realized can be adjusted to personal abilities and (b) is not prone to discouragement due to the level of difficulty or anxiety about mathematics. The latter has been suggested as a major factor in students being less motivated to study physics (Carter and Erna 2017), which the Chain Experiment could overcome. Some authors have also indicated that one of the most effective ways to introduce science is in a game environment (Di Sia 2017; Isbister et al. 2012), or by presenting it in the form of active learning instead of traditional lecture-based teaching (Freeman et al. 2014). The Chain Experiment competition fulfils these conditions and can be a good way to encourage students to learn physics. Moreover, showing participants that physical laws do work in real life and that they might be a tool for incredible inventions can convince them to accept the 'validity' of physics. The practical form of the contest can embolden students who are afraid of calculations.

The findings summarized in RQ3-5 are supported by analysing the sources of students' knowledge, which showed that most participants used more than one (or even more than a few) sources of knowledge. This implicates a few reflections. First, the participants broadened their knowledge, and for this purpose they used mainly informal sources other than school classes and books, which indicate that searching for knowledge and ideas goes beyond curricula. Second, they were motivated enough to look for different ideas through various channels, this the Chain Experiment also has a motivational role. Finally, only as a presumption, searching for various practical aspects of physics might influence participants' interest in physics by establishing the connection between school knowledge and out-of-school experiences.

Let us also discuss briefly the data obtained across the age categories. In general, the mostpositive answers were given by PS and HS participants, while among L-SS participants, the average results are lower. L-SS students seem less interested than all other age groups in physics or science, they are less motivated to gain new knowledge, and they remain even less likely to improve their soft skills after participating in the competition. It has been suggested that this phenomenon might be related to the constantly shifting objects of interest in this age group and the relatively low interest in topics that are close to what is found in science curricula and textbooks (Sjøberg and Schreiner 2010). Comparing PS and L-SS students has indicated that the latter are oriented more towards practical issues (e.g. nutrition, modern diseases or phenomenon that science cannot explain) than areas such as biology or technology in general (Jidesjö 2008; Anderhag et al. 2016). Based on this, we assume that our observations are also influenced by the specificity of this age group. Many reasons have been proposed for the decline in interest in science during the transition from primary to secondary school: the lack of science in PS (Tytler et al. 2008), the new educational environment (Speering and Rennie 1996), and the emotional changes that are typical for this group (Schukajlow et al. 2017). At the same time, recent research has shown that gamification might be an effective approach to motivating and engaging students in this particular age group to learn (Hong and Masood 2014).

Based on participants' opinions, most of them were previously interested in physics or science; however, note that $25 \%$ of the contestants were attending PS, where physics is not 
a separate subject. The results indicate that with respect to scientific knowledge, this age category benefits most from participating in the Chain Experiment competition. Accordingly, they report being more motivated to gain new knowledge and more interested in physics in general, which corresponds with recent findings (Blumenfeld et al. 1991; Kaldi et al. 2011; Hwang et al. 2014). Those authors suggest that a method of learning that begins with experiments, proceeds to construction and then adds theory when students are already engaged in a task encourages them in physics and science. Moreover, introducing physics as a practical science that is strongly related to engineering presents this knowledge domain to potentially more students, providing them with meaningful real-world challenges (Boss and Krauss 2014). Arousing natural curiosity in physical sciences is particularly important for students who, at this educational level, do not learn physics as a separate subject at school (Obe and Qualter 2014). Moreover, it has been shown that including elements of experimentation at a very early level of education is a particularly beneficial way to introduce basic scientific concepts and principles (Zhai et al. 2014).

To conclude, the Chain Experiment competitions might have a positive influence on various aspects of participants' development, including soft skills, motivation and scientific knowledge. Nevertheless, the present research was based on participants' and mentors' opinions as well as jury members' observations, thereby allowing us to formulate only tentative findings (as mentioned as a limitation in the Methodology section). Furthermore, morespecific instruments are required for moredetailed further research. The most important added value of the Chain Experiment is that improvement of soft skills is amalgamated with improvement and increase of knowledge. This makes the Chain Experiment a unique competition and an informal learning approach.

\section{Conclusions}

The Chain Experiment is an annual competition that has been held since 2013 by students from Jagiellonian University in Cracow, Poland. The principal goal is to design and construct a machine that applies interesting physics phenomena to transport a steel ball to the next device in the chain by triggering the presentation of various physics laws and creative mechanisms. The finale of the competition brings together a relatively constant number of participants in front of an enthusiastic audience (Dziob et al. 2017). Apart from the fact that it is a contest in which participating teams compete with one another, its finale is also a physics show - a unique festival of physics.

In this paper, we have shown that active participation in such competitions increases soft skills, motivates physics learning and increases scientific knowledge. The form of the competition, for which not only theoretical but also practical information and engineering skills are needed, might motivate participants to take part in similar challenges. We claim that the Chain Experiment competition seems to motivate participants to work, possibly resulting in a quicker and more effective process of gaining knowledge and improving soft skills.

The Chain Experiment competition encourages conceptual reasoning and could be a way to introduce physics in a more accessible way than classic school lessons. In our opinion, its practical usage creates an alternative in education that could be particularly valuable in the current world of rapid technological development. Giving a specific task to construct a contraption motivates participants to discover physics individually and possibly encourages them to further develop their scientific knowledge on their own. All the arguments mentioned herein are in favour of the specific idea of the Chain Experiment competition, which 
allows various educational approaches to be combined and employed (i.e. collaborative learning, PBL and gamification), wrapped in the framework of design education.

Open Access This article is licensed under a Creative Commons Attribution 4.0 International License, which permits use, sharing, adaptation, distribution and reproduction in any medium or format, as long as you give appropriate credit to the original author(s) and the source, provide a link to the Creative Commons licence, and indicate if changes were made. The images or other third party material in this article are included in the article's Creative Commons licence, unless indicated otherwise in a credit line to the material. If material is not included in the article's Creative Commons licence and your intended use is not permitted by statutory regulation or exceeds the permitted use, you will need to obtain permission directly from the copyright holder. To view a copy of this licence, visit http://creativecommons.org/licenses/by/4.0/.

\section{Appendix 1: Participant questionnaire}

\section{Part 1: Mark " $X$ " on the number line to show how much your skills/abilities/ knowledge have changed due to participation in the Chain Experiment competition}

1. Communication skills

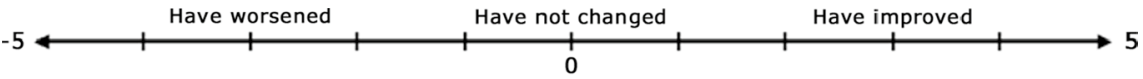

2. Interest in physics/science

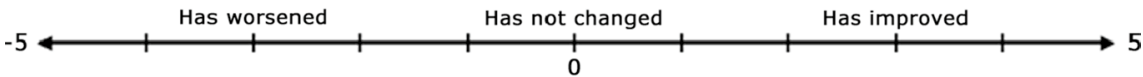

3. Ability to discuss

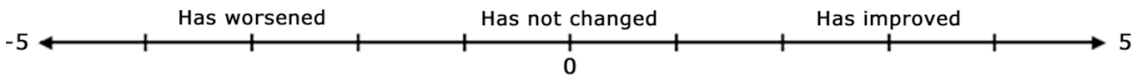

4. Knowledge of physics

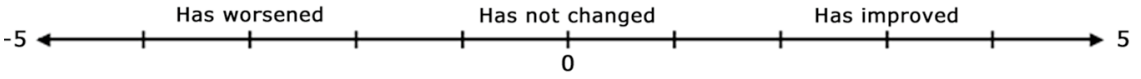

5. Ability to search for information

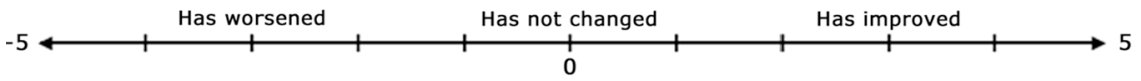

6. Ability to present your own opinion

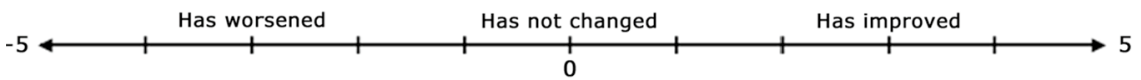

7. Openness to new challenges

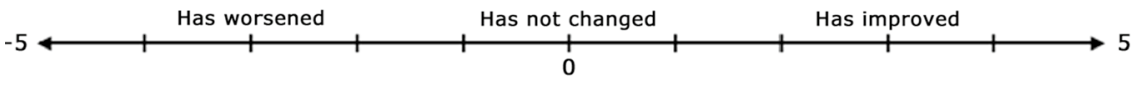

8. Interest in do-it-yourself activities

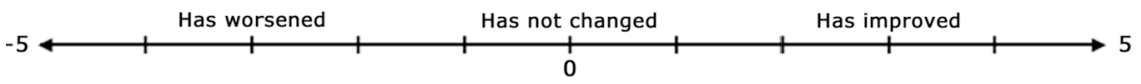


Part 2: Indicate the learning resources you used most frequently during preparation of your contraption (tick as many boxes as you like)

chool classes

$\square$ additional classes with mentor

$\square$ school books

$\square$ books other than school books

$\square$ courses outside school

$\square$ activities in community centres

Dother (which ones?): internet

$\square$ scientific movies

$\square$ parents

lings

\section{Part 3: Rate your agreement with the sentences below on the five-point scale}

\begin{tabular}{|c|c|c|c|c|c|}
\hline & $\begin{array}{l}\text { Strongly } \\
\text { disagree }\end{array}$ & Disagree & $\begin{array}{l}\text { Neither } \\
\text { agree nor } \\
\text { disagree }\end{array}$ & Agree & $\begin{array}{l}\text { Strongly } \\
\text { agree }\end{array}$ \\
\hline & 1 & 2 & 3 & 4 & 5 \\
\hline $\begin{array}{l}\text { 1. During the preparation of the contraption I } \\
\text { learned new physical phenomena }\end{array}$ & $\square$ & $\square$ & $\square$ & $\square$ & $\square$ \\
\hline $\begin{array}{l}\text { 2. Working on the contraption increased my } \\
\text { interests in physics }\end{array}$ & $\square$ & $\square$ & $\square$ & $\square$ & $\square$ \\
\hline $\begin{array}{l}\text { 3. Working on the contraption strengthened my will } \\
\text { to learn physics and science }\end{array}$ & $\square$ & $\square$ & $\square$ & $\square$ & $\square$ \\
\hline $\begin{array}{l}\text { 4. Preparation of the contraption required } \\
\text { knowledge beyond the school curriculum }\end{array}$ & $\square$ & $\square$ & $\square$ & $\square$ & $\square$ \\
\hline $\begin{array}{l}\text { 5. Realization of the task in a group allowed } \\
\text { problems to be solved more efficiently }\end{array}$ & $\square$ & $\square$ & $\square$ & $\square$ & $\square$ \\
\hline $\begin{array}{l}\text { 6. Realization of the task in a group developed my } \\
\text { communication skills }\end{array}$ & $\square$ & $\square$ & $\square$ & $\square$ & $\square$ \\
\hline 7. Competing with other teams was motivating & $\square$ & $\square$ & $\square$ & $\square$ & $\square$ \\
\hline $\begin{array}{l}\text { 8. After participating in the Chain Experiment I } \\
\text { would like to try another similar competition }\end{array}$ & $\square$ & $\square$ & $\square$ & $\square$ & $\square$ \\
\hline
\end{tabular}




\section{Part 4: Rate the following sentences on the five-point scale}

\begin{tabular}{|c|c|c|c|c|c|}
\hline & $\begin{array}{l}\text { Strongly } \\
\text { disagree }\end{array}$ & Disagree & $\begin{array}{l}\text { Neither } \\
\text { agree nor } \\
\text { disagree }\end{array}$ & Agree & $\begin{array}{l}\text { Strongly } \\
\text { agree }\end{array}$ \\
\hline & 1 & 2 & 3 & 4 & 5 \\
\hline $\begin{array}{l}\text { 1. Working in a group encouraged my participation } \\
\text { in the competition }\end{array}$ & $\square$ & $\square$ & $\square$ & $\square$ & $\square$ \\
\hline $\begin{array}{l}\text { 2. Working in a group encouraged me to learn } \\
\text { physics/science }\end{array}$ & $\square$ & $\square$ & $\square$ & $\square$ & $\square$ \\
\hline $\begin{array}{l}\text { 3. Working in a group stimulated me to bring new } \\
\text { ideas }\end{array}$ & $\square$ & $\square$ & $\square$ & $\square$ & $\square$ \\
\hline $\begin{array}{l}\text { 4. Working in a group decreased stress while } \\
\text { accomplishing the task }\end{array}$ & $\square$ & $\square$ & $\square$ & $\square$ & $\square$ \\
\hline $\begin{array}{l}\text { 5. Working in a group facilitated the solving of } \\
\text { problems and accomplishing the task }\end{array}$ & $\square$ & $\square$ & $\square$ & $\square$ & $\square$ \\
\hline $\begin{array}{l}\text { 6. Working in a group facilitated finding the answers } \\
\text { (during preparations and during assessment by } \\
\text { judges in the Grand Finale) }\end{array}$ & $\square$ & $\square$ & $\square$ & $\square$ & $\square$ \\
\hline
\end{tabular}

\section{Appendix 2: Mentor Questionnaire}

Rate your agreement with the sentences below on the five-point scale

\begin{tabular}{|c|c|c|c|c|c|}
\hline & $\begin{array}{l}\text { Strongly } \\
\text { disagree }\end{array}$ & Disagree & $\begin{array}{l}\text { Neither } \\
\text { agree nor } \\
\text { disagree }\end{array}$ & Agree & $\begin{array}{l}\text { Strongly } \\
\text { agree }\end{array}$ \\
\hline & 1 & 2 & 3 & 4 & 5 \\
\hline $\begin{array}{l}\text { 1. During preparation of the contraption, } \\
\text { participants learned new physical phenomena }\end{array}$ & $\square$ & $\square$ & $\square$ & $\square$ & $\square$ \\
\hline $\begin{array}{l}\text { 2. Preparation of the contraption required } \\
\text { participants to use knowledge beyond the standard } \\
\text { curriculum }\end{array}$ & $\square$ & $\square$ & $\square$ & $\square$ & $\square$ \\
\hline $\begin{array}{l}\text { 3. Working on the contraption increased the } \\
\text { participants' interest in physics/science }\end{array}$ & $\square$ & $\square$ & $\square$ & $\square$ & $\square$ \\
\hline $\begin{array}{l}\text { 4. Working on the contraption increased the partici- } \\
\text { pants' motivation to learn physics and science }\end{array}$ & $\square$ & $\square$ & $\square$ & $\square$ & $\square$ \\
\hline $\begin{array}{l}\text { 5. Working in a group facilitated solving problems } \\
\text { and accomplishing the task }\end{array}$ & $\square$ & $\square$ & $\square$ & $\square$ & $\square$ \\
\hline $\begin{array}{l}\text { 6. Working in a group decreased stress during the } \\
\text { assessment in the Great Finale }\end{array}$ & $\square$ & $\square$ & $\square$ & $\square$ & $\square$ \\
\hline $\begin{array}{l}\text { 7. Realization of the task in a group developed the } \\
\text { participants' communication skills }\end{array}$ & $\square$ & $\square$ & $\square$ & $\square$ & $\square$ \\
\hline $\begin{array}{l}\text { 8. Participation in the contest encouraged par- } \\
\text { ticipants to take on new scientific challenges in } \\
\text { physics/science }\end{array}$ & $\square$ & $\square$ & $\square$ & $\square$ & $\square$ \\
\hline
\end{tabular}




\begin{tabular}{llllll}
\hline & $\begin{array}{l}\text { Strongly } \\
\text { disagree }\end{array}$ & $\begin{array}{l}\text { Disagree } \\
\text { Neither } \\
\text { agree nor } \\
\text { disagree }\end{array}$ & $\begin{array}{l}\text { Agree } \\
\text { Strongly } \\
\text { agree }\end{array}$ \\
\hline $\begin{array}{c}\text { 9. Participation in the contest helped reduce partici- } \\
\text { pants' stress in classes and increased their interest }\end{array}$ & $\square$ & $\square$ & $\square$ & $\square$ & $\square$ \\
$\begin{array}{c}\text { in physics/science as a school subject } \\
\begin{array}{c}\text { 10. Working on contraptions helped participants } \\
\text { better understand physics learning material }\end{array}\end{array}$ & $\square$ & $\square$ & $\square$ & $\square$ & $\square$ \\
$\begin{array}{l}\text { 11. After the contest, participants' scores in physics/ } \\
\text { science improved }\end{array}$ & $\square$ & $\square$ & $\square$ & $\square$ & $\square$ \\
\hline
\end{tabular}

\section{Appendix 3: Semi-structured interview with jury members}

\section{Set 1: Students knowledge and contraption preparation}

- What, in your opinion, was the level of participants' work?

- In your opinion, did the phenomena presented in the participants' work go beyond the curriculum?

- Were the participants able to explain these phenomena properly?

\section{Set 2: Group work}

- How do you assess group work?

- Did all participants collaborate and present and explain the operation of the device, or was one leader visible?

- In your opinion, did the participants cooperate in creating the device?

\section{Set 3: Unusual phenomena and solutions}

- Have there been any solutions that particularly stuck in your mind?

\section{References}

Aikenhead, G. (2006). Science education for everyday life. New York, NY: Teachers' College Press.

Albanese, M., \& Mitchell, S. (1993). Problem-based learning: A review of literature on its outcomes and implementation issues. Academic Medicine, 68, 52-81.

Anderhag, P., Wickman, P. O., Bergqvist, K., Jakobson, B., Hamza, K. M., \& Säljö, R. (2016). Why do secondary school students lose their interest in science? Or does it never emerge? A possible and overlooked explanation. Science Education, 100(5), 791-813.

Apostol, S., Zaharescu, L., \& Aleze, I. (2013). Gamification of learning and educational games. eLearning and Software for Education, 2, 67.

Azmir, A. M. N., Rahim, A. M., \& Sulaiman, A. (2011). Cooperative learning approach to improve softskills among university student. Elixir Leader Management, 34(2011), 2530-2534.

Banfield, J., \& Wilkerson, B. (2014). Increasing student intrinsic motivation and self-efficacy through gamification pedagogy. Contemporary Issues in Education Research CIER, 7(4), 291. 
Barkley, E. F., Major, C. H., \& Cross, K. P. (2014). Collaborative learning techniques: A resource for college faculty (2nd ed.). San Francisco, CA: Jossey-Bass.

Barron, B. J. S., Schwartz, D. L., Vye, N. J., Moore, A., Petrosino, A., Zech, L., et al. (1998). Doing with understanding: Lessons from research on problem- and project-based learning. Journal of the Learning Sciences, 7, 3-4.

Bell, P., Lewenstein, B., Shouse, A. W., \& Feder, M. A. (2009). Learning science in informal environments: People, places, and pursuits. Washington, DC: National Academies Press.

Bereiter, C., \& Scardamalia, M. (2003). Learning to work creatively with knowledge. In E. De Corte, L. Verschaffel, N. Entwistle, \& J. van Merriënboer (Eds.), Powerful learning environments: Unraveling basic components and dimensions (pp. 55-68). Oxford, UK: Elsevier Science.

Berk, S. (2016). Designing for the future of education requires design education. Art Education, 69(6), 16-20.

Blom, A., \& Saeki, H. (2011). Employability and skill set of newly graduated engineers in India. New Delhi: World Bank.

Blumenfeld, P. C., Soloway, E., Marx, R. W., Krajcik, J. S., Guzdial, M., \& Palniscar, A. (1991). Motivating project-based learning: Sustaining the doing, supporting the learning. Educational Psychologist, 26, 369-398.

Boss, S., \& Krauss, J. (2014). Reinventing project-based learning: Your field guide to real-world projects in the digital age. Washington, DC: International Society for Technology in Education.

Brickhouse, N. W., \& Potter, J. T. (2001). Young women's scientific identity formation in an urban context. Journal of Research in Science Teaching, 38(8), 965-980.

Broughton, S. H., Sinatra, G. M., \& Nussbaum, E. M. (2013). "Pluto has been a planet my whole life!" Emotions, attitudes, and conceptual change in elementary students learning about Pluto's reclassification. Research in Science Education, 43(2), 529-550.

Brown, R. A., \& Brown, J. W. (2010). What is technology education? a review of the "Official Curriculum". The Clearing House: A Journal of Educational Strategies, Issues and Ideas, 83(2), 49-53.

Burguillo, J. C. (2010). Using game theory and competition-based learning to stimulate student motivation and performance. Computers \& Education, 55(2), 566-575.

Calabrese Barton, A. (1998). Reframing science for all through the politics of poverty. Educational Policy, $12,525-541$.

Calabrese Barton, A. (2003). Teaching science for social justice. New York, NY: Teachers College Press.

Campbell, J. R., \& Walberg, H. J. (2010). Olympiad studies: Competitions provide alternatives to developing talents that serve national interests. Roeper Review, 33, 8-17.

Carter, C., \& Erna, Y. (2017). Math anxiety in the science classroom. The Hoosier Science Teacher, 40(1), 27-32.

Casakin, H., \& Goldschmidt, G. (1999). Expertise and the use of visual analogy: Implications for design education. Design Studies, 20(2), 153-175.

Chain Experiment. http://149.156.64.22/Lancuch/wp-content/uploads/2018/12/Eksperyment-\%C5\%81a\%C5\%84cuc howy-Regulamin.pdf.

Cheong, C. (2010). From group-based learning to cooperative learning: A metacognitive approach to project-based group supervision. International Journal of an Emerging Transdiscipline, 13, 73-86.

Clara, S. F. B., Singai, C. B., \& Saheed, O. (2018). Soft skills for young adults: Circuit in the formal, nonformal and informal models. Issues and Ideas in Education, 6(1), 97-110.

Cobern, W. W. (1996). Worldview theory and conceptual change in science education. Science Education, $80(5), 579-610$.

Collins, A., Brown, J. S., \& Newman, S. (1989). Cognitive apprenticeship: Teaching the crafts of reading, writing and mathematics. In L. B. Resnick (Ed.), Knowing, learning and instruction (pp. 453-494). Hillsdale, NJ: Erlbaum.

Conklin, A. (2006). Cyber defence competitions and information security education: An active learning solution for a capstone course. In Proceedings of the 39th annual Hawaii international conference on system sciences, 2006. HICSS'06 (Vol. 9, pp. 220b-220b). IEEE.

Davidson, N., \& Major, C. H. (2014). Boundary crossings: Cooperative learning, collaborative learning, and problem-based learning. Journal on Excellence in College Teaching, 25, 7-55.

Des Marchais, J. E. (1999). A Delphi technique to identify and evaluate criteria for construction of PBL problems. Medical Education, 33, 504-508.

Deterding, S., Sicart, M., Nacke, L., O’Hara, K. \& Dixon, D. (2011). Gamification: Using game-design elements in non-gaming contexts. In Proceedings of the 2011 annual conference on human factors in computing systems (p. 2425). Vancouver, US. 
Di Sia, P. (2017). Learning mathematics through games in primary school: An applicative path. Edutainment, 1(1), 127-133.

Dicheva, D., Dichev, C., Agre, G., \& Angelova, G. (2015). Gamification in education: A systematic mapping study. Educational Technology and Society, 18(3), 75-88.

Dierking, L., Falk, J., Rennie, L., Anderson, D., \& Ellenbogen, K. (2003). Policy statement of the "informal science education" ad hoc committee. Journal of Research in Science Teaching, 44(2), 108-111.

Dochie, E., Herman, C., \& Epure, C. (2017). Using gamification for the development of soft skills. Skill generator assessment game case study. In The international scientific conference eLearning and software for education; Bucharest Issue 3 (pp. 610-613).

Dugger, V., \& Naik, N. (2001). Clarifying misconceptions between technology education and educational technology. The Technology Teacher, 61(1), 31-35.

Dziob, D., Górska, U., \& Kołodziej T. (2016). Eksperyment Łańcuchowy, czyli jak fizyka może być inspirująca, ciekawa i twórcza na każdym etapie edukacji. Wydział Fizyki, Astronomii i Informatyki Stosowanej Uniwersytetu Jagiellońskiego. ISBN 978-83-945937-2-8.

Dziob, D., Górska, U., \& Kołodziej, T. (2017). Chain experiment competition inspires learning of physics. European Journal of Physics, 38, 034002.

English, M. C., \& Kitsantas, A. (2013). Supporting student self-regulated learning in problem-and projectbased learning. Interdisciplinary Journal of Problem-Based Learning, 7(2), 6.

Enos, M. D., Kehrhahn, M. T., \& Bell, A. (2003). Informal learning and the transfer of learning: How managers develop proficiency. Human Resources Development Quarterly, 14(4), 369-387.

Evensen, D. (2000). Observing self-directed learners in a problem-based learning context: Two case studies. In D. Evensen \& C. E. Hmelo (Eds.), Problem-based learning: A research perspective on learning interactions (pp. 263-297). Mahwah, NJ: Erlbaum.

Falk, J. H., \& Dierking, L. D. (2010). The 95 percent solution school is not where most Americans learn most of their science. American Scientist, 98(6), 486-493.

Fallik, O., Rosenfeld, S., \& Eylon, B. (2013). School and out-of-school science: A model for bridging the gap. Studies in Science Education, 49(1), 69-91.

Fensham, P. J. (2004). Defining an identity: The evolution of science education as a field of research. Boston: Kluwer Academic. (Change into extending science...).

Freeman, S., Eddy, S. L., McDonough, M., Smith, M. K., Okoroafor, N., Jordt, H., et al. (2014). Active learning increases student performance in science, engineering, and mathematics. Proceedings of the National Academy of Sciences, 111(23), 8410-8415.

Fusco, D., \& Calabrese Barton, A. (2001). Representing student achievements in science. Journal of Research in Science Teaching, 38(3), 337-354.

Gallagher, S. A. (1997). Problem-based learning: Where did it come from, what does it do, and where is it going? Journal for the Education of the Gifted, 20, 332-362.

Gilbert, J. K., Boulter, C. J., \& Elmer, R. (2000). Positioning models in science education and in design and technology education. In J. K. Gilbert \& C. J. Boulter (Eds.), Developing Models in Science Education. Dordrecht: Springer.

Gunawardena, C., Lowe, C., \& Anderson, T. (1997). Analysis of a global on-line debate and the development of an interaction analysis model for examining social construction of knowledge in computer conferencing. Journal of Educational Computing Research, 17(4), 395-429.

Hakkarainen, K. (2009). A knowledge-practice perspective on technology-mediated learning. International Journal of Computer-Supported Collaborative Learning, 4(2), 213-231.

Hamilton, M. (2008). No jacket required: Informal learning's role in development. Chief Learning Officer, $7(5), 46-49$.

Hanus, M., \& Fox, J. (2015). Assessing the effects of gamification in the classroom: A longitudinal study on intrinsic motivation, social comparison, satisfaction, effort, and academic performance. Computers \& Education, 80, 152-161. 
Haskell, H., Britton, C., \& Edge, R. (2000). A different kind of physics competition-The IYPT. The Physics Teacher, 38(1), 22.

Haupt, G. (2017). Design in technology education: Current state of affairs. In M. de Vries (Ed.), Handbook of Technology Education. Cham: Springer International Handbooks of Education, Springer.

Heckman, J. J., \& Kautz, T. (2012). Hard evidence on soft skills. Labour Economics, 19(4), 451-464.

Hmelo-Silver, C. E. (2004). Problem-based learning: What and how do students learn? Educational Psychology Review, 16, 235-266.

Hong, G. Y., \& Masood, M. (2014). Effects of gamification on lower secondary school students' motivation and engagement. International Journal of Social, Education, Economics and Management Engineering, 8(12), 3483-3490.

Huotari, K., \& Hamari, J. (2012). Defining gamification: A service marketing perspective. In Proceedings of the 16th international academic MindTrek conference 2012, Tampere, Finland, October 3-5.

Hwang, G. J., Hung, C. M., \& Chen, N. S. (2014). Improving learning achievements, motivations and problem-solving skills through a peer assessment-based game development approach. Educational Technology Research and Development, 62(2), 129-145.

Idrus, H., \& Abdullah, M. R. (2018). Implementation of PBL to enhance the soft skills of engineering student. In International conference on humanities and social sciences (ICHSS 2018), SHS web conference (vol. 53).

Ifenthaler, D., Eseryel, D., \& Ge, X. (2012). Assessment in game-based learning: Foundations, innovations, and perspectives. New York: Springer.

Isbister, K., Karlesky, M., Frye, J. \& Rao, R. (2012). Scoop!: A movement-based math game designed to reduce math anxiety. In CHI'12 extended abstracts on human factors in computing systems (pp. 1075-1078). ACM.

Jenkins, E. W., \& Nelson, N. W. (2005). Important but not for me: Students' attitudes towards secondary school science in England. Research in Science and Technological Education, 23, 41-57.

Jidesjö, A. (2008). Different content orientations in science and technology among primary and secondary boys and girls in Sweden: Implications for the transition from primary to secondary school? Nordic Studies in Science Education, 4(2), 192-208.

Johnson, D. W., \& Johnson, R. T. (2014). Cooperative learning in 21st century. Anales de Psicología/Annals of Psychology, 30(3), 841-851.

Johnson, D. W., Johnson, R. T., \& Holubec, E. J. (2013). Cooperation in the classroom (9th ed.). Edina, $\mathrm{MN}$ : Interaction Book Company.

Jordens, H., \& Mathelitsch, L. (2009). Physics competitions. European Journal of Physics, 30(6), S101.

Kaldi, S., Filippatou, D., \& Govaris, C. (2011). Project-based learning in primary schools: Effects on pupils' learning and attitudes. Education, 39(1), 35-47.

Kapitanoff, S. H. (2009). Collaborative testing: Cognitive and interpersonal processes related to enhanced test performance. Active Learning in Higher Education, 10(1), 56-70.

Khalid, M., \& Metersad, M. (2016). Cooperative learning strategies to develop and assess values and dost skills among technical and vocational students. In Proceedings of the international conference on education towards global peace.

Klein, B. D., Davis, T. A., \& Kridli, G. (2015). Building a rube goldberg machine in an undergraduate business school course to learn principles of project management and leadership skills. Journal of the Midwest Association for Information Systems, 1, 53-66.

Kuo, F. R., Hwang, G. J., \& Lee, C. C. (2012). A hybrid approach to promoting students' web-based problem solving competence and learning attitude. Computers \& Education, 58, 351-364.

Langdon, D., McKittrick, G., Beede, D., Khan, B., \& Doms, M. (2011). STEM: Good jobs now and for the future. ESA Issue Brief \#03-11.

Lawson, B. (2006). How designers think: The design process demystified (4th edn). Oxford, Burlington, MA: Elsevier/ Architectural Press.

Lee, H.-J., \& Lim, C. (2012). Peer evaluation in blended team project-based learning: What do students find important? Educational Technology and Society, 15(4), 214-224.

Lejk, M., \& Wyvill, M. (2001). Peer assessment of contributions to a group project: A comparison of holistic and category-based approaches. Assessment and Evaluation in Higher Education, 26(1), 61-72.

Loyens, S. M., Jones, S. H., Mikkers, J., \& van Gog, T. (2015). Problem-based learning as a facilitator of conceptual change. Learning and Instruction, 38, 34-42.

Mallya, A., Mensah, F. M., Contento, I. R., Koch, P. A., \& Calabrese Barton, A. (2012). Extending science beyond the classroom door: Learning from students' experiences with the choice, control and change (C3) curriculum. Journal of Research in Science Teaching, 49(2), 244-269.

McNamara, S., Cyr, M., Rogers, C., \& Bratzel, B. (1999). LEGO brick sculptures and robotics in education. In ASEE Proc. 
Meltzer, D. (2002). The relationship between mathematics preparation and conceptual learning gains in physics: A possible "hidden variable" in diagnostic pretest scores. American Journal of Physics, 70, 1259.

Mitcham, C. (2001). Dasein versus design: The problematics of turning making into thinking. International Journal of Technology and Design Education, 11(1), 27-36.

Moncada, S., \& Moncada, T. (2014). Gamification of learning in accounting education. Journal of Higher Education Theory and Practice, 14, 9.

Newman, D., Webb, B., \& Cochrane, C. (1995). A content analysis method to measure critical thinking in face-to-face and computer supported group learning. Interpersonal Computing and Technology: An Electronic Journal, 3(2), 56-77.

Obe, W. H., \& Qualter, A. (2014). The teaching of science in primary schools. London: Routledge.

Osborne, J., \& Collins, S. (2001). Pupils' views of the role and value of the science curriculum: A focusgroup study. International Journal of Science Education, 23, 441-467.

Osborne, J., \& Dillon, J. (2008). Science education in Europe: Critical reflections. London: King's College.

Ovesen, N. (2015). The problem revisited: Teaching the PBL approach to design students. In G. Bingham, D. Southee, J. McCardle, A. Kovacevic, E. Bohemia, \& B. Parkinson (Eds.), Great Expectations: Design teaching, research \& enterprise: Proceedings of the 17th international conference onengineering and product design education (pp. 500-505). Design Society.

Ozturk, M. A., \& Debelak, C. (2008). Affective benefits from academic competitions for middle school gifted students Gifted. Children Today, 31(2), 48-53.

Paradise, R., \& Rogoff, B. (2009). Side by side: Learning by observing and pitching in. Journal of the Society for Psychological Anthropology, 37, 102-138.

Pawson, A. (2016). Collaborative learning in design education: The value of collaboration and collective experience in team projects. The International Journal of Design Education, 10(3), 65-72. https:// doi.org/10.18848/2325-128X/CGP/v10i03/65-72.

Pena-Perez, J. (2000). Participation, interaction and meaning construction in a university-level course using a computer bulletin board as a supplement to regular class discussions: A case study. Unpublished doctoral dissertation, Cornell University, Ithaca, NY.

Rahm, J. (2002). Emergent learning opportunities in an inner-city youth gardening program. Journal of Research in Science Teaching, 39(2), 164-184.

Rennie, J. R. (2007). Learning science outside of school. In S. K. Abell \& N. G. Lederman (Eds.), Handbook of research on science education (pp. 125-167). Mahwah, NJ: Erlbaum.

Robles, M. M. (2012). Executive perceptions of the top 10 soft skills needed in today's workplace. Business Communication Quarterly, 75(4), 453-465.

Robson, K., Plangger, K., Kietzmann, J., McCarthy, I., \& Pitt, L. (2015). Is it all a game? Understanding the principles of gamification. Business Horizons, 58(4), 411-420.

Roehl, A., Reddy, S. L., \& Shannon, G. J. (2013). The flipped classroom: An opportunity to engage millennial students through active learning. Journal of Family and Consumer Sciences, 105(2), 44.

Sadler, T. D., Romine, W. L., Stuart, P. E., \& Merle-Johnson, D. (2013). Game-based curricula in biology classes: Differential effects among varying academic levels. Journal of Research in Science Teaching, 50(4), 479-499.

Santos, C. E. O., Senti, V. E., Rodriguez, J. P. F., \& Maldonado, C. O. (2017). Importance of soft skills training from an early age. International Research Journal of Engineering and Technology, 4(5), 1-8.

Savery, J. R. (2006). Overview of problem-based learning: Definitions and distinctions. Interdisciplinary Journal of Problem-Based Learning. https://doi.org/10.7771/1541-5015.1002.

Schellens, T., \& Valcke, M. (2005). Collaborative learning in asynchronous discussion groups: What about the impact on cognitive processing? Computers in Human Behavior, 21(6), 957-975.

Schmidt, H. G., Jerome, I. R., \& Elaine, H. J. (2011). The process of problem-based learning: What works and why. Medical Education, 45, 792-806.

Schukajlow, S., Rakoczy, K., \& Pekrun, R. (2017). Emotions and motivation in mathematics education: Theoretical considerations and empirical contributions. ZDM Mathematics Education, 49, 1-16.

Schulz, B. (2008). The importance of soft skills: Education beyond academic knowledge. Journal of Language and Communication, 2, 146-154.

Schuster, P., \& Davol, A., \& Mello, J. (2006). Student competitions: The benefits and challenges. Paper presented at 2006 annual conference and exposition, Chicago, IL. https://peer.asee.org/1055.

Seaborn, K., \& Fels, D. I. (2015). Gamification in theory and action: A survey. International Journal of Human-Computer Studies, 74, 14-31.

Sjøberg, S., \& Schreiner, C. (2005). How do learners in different cultures relate to science and technology? Asia-Pacific Forum on Science Learning and Teaching, 6, 1-17. 
Sjøberg, S., \& Schreiner, C. (2010). The ROSE project: An overview and key findings (pp. 1-31). Oslo: University of Oslo.

Speering, W., \& Rennie, L. (1996). Students' perceptions about science: The impact of transition from primary to secondary school. Research in Science Education, 26(3), 283-298.

Springer, L., Stanne, M. E., \& Donovan, S. (1999). Effects of small-group learning on undergraduates in science, mathematics, engineering, and technology: A meta-analysis (Research Monograph No. 11). Review of Educational Research, 69, 21-51.

Stahl, G. (2000). A Model of Collaborative Knowledge-Building. In B. Fishman \& S. O'Connor-Divelbiss (Eds.), Fourth International Conference of the Learning Sciences (pp. 70-77). Mahwah, NJ: Erlbaum.

Sung, H., \& Hwang, G. (2013). A collaborative game-based learning approach to improving students' learning performance in science courses. Computers \& Education, 63, 43-51.

Susman, K., Ziherl, S., \& Bajc, J. (2017). Ten years of the project Chain Experiment. European Journal of Physics, 38(3), 034012.

Symonds, W. C., Schwartz, R., \& Ferguson, R. F. (2011). Pathways to prosperity: Meeting the challenge of preparing young Americans for the 21st century. Cambridge, MA: Pathways to Prosperity Project, Harvard University Graduate School of Education.

Tal, T., \& Dierking, L. (2014). Learning science in everyday life. Journal of Research in Science Teaching, 51(3), 251-295.

Thrasher, T. N. (2008). The benefits of mathematics competitions Alabama. Journal of Mathematics, 32, 59-63.

Trevor, K. E., Gregory, L. N., \& Sean, P. S. (2020). Using collaborative learning to develop students' soft skills. Journal of Education for Business, 95(2), 106-114.

Tytler, R., Osborne, J., Williams, G., Tytler, K., \& Cripps Clark, J. (2008). Opening up pathways: Engagement in STEM across the primary-secondary school transition.

Verma, G., Puvirajah, A., \& Webb, H. (2015). Enacting acts of authentication in a robotics competition: An interpretivist study. Journal of Research in Science Teaching, 52, 268-295.

Vernon, D. T., \& Blake, R. L. (1993). Does problem-based learning work? A meta-analysis of evaluative research. Academic Medicine, 68, 550-563.

Wankat, P. C. (2005). Undergraduate student competitions. Journal of Engineering Education, 94, $343-347$.

Zadeh, M. Y., \& Satır, S. (2015). Instruction of applied physics in industrial product design. Procedia Social and Behavioral Sciences, 182, 20-28.

Zhai, J., Jocz, J. A., \& Tan, A. L. (2014). 'Am I Like a Scientist?': Primary children's images of doing science in school. International Journal of Science Education, 36(4), 553-576.

Zhang, A. (2012). Cooperative learning and soft skills training in an IT course. Journal of Information Technology Education, 11, 155-168.

Publisher's Note Springer Nature remains neutral with regard to jurisdictional claims in published maps and institutional affiliations. 